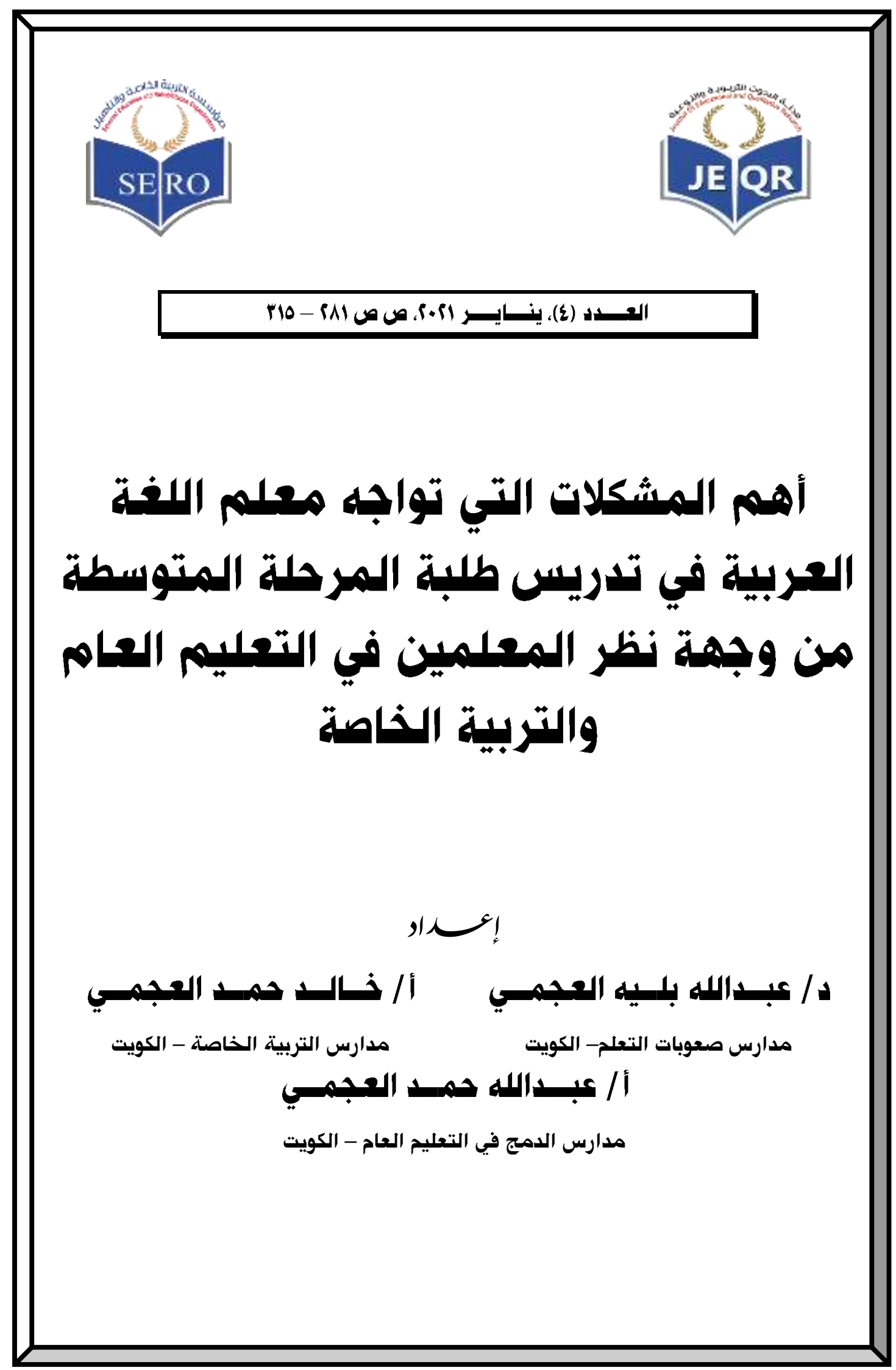




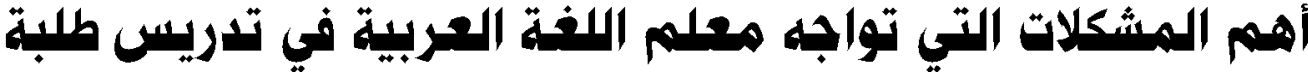

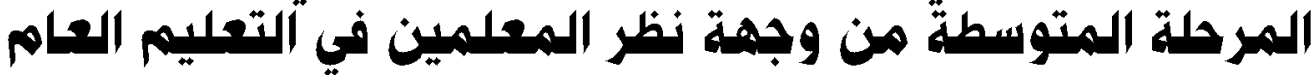 والتربية الناصة بطة}

د/ عبدالله المجمي \&(*) أ/ خالد المجمي (**) \& أ/ عبدالله المجمي (**)

\section{هلنـــص الــدراسـيسة}

هدفت الدراسـة للوقوف على أهم المشكلات وأكثرهـا شيوعاً لدى معلمي ومعلمات اللغنة العربية في التعليم العام والتربية الخاصة من وجهة نظرهم، كما تهدف إلى أثر متغيرات كل من:

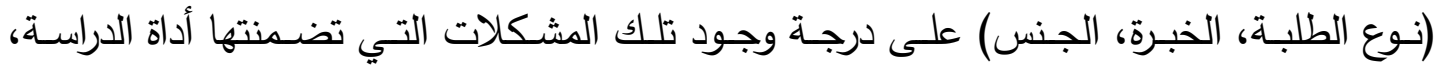
واستخدم الباحثين مقياساً من إعدادهم، وبلغت عينة الدراسة التي اختيرت بطريقة عشوائية (. ب (ب) معلماً ومعلمة، وأسفرت الدراسة عن عدة نتائج من أهمها: أن أهم المشكلات التي تواجها التها المعلمين

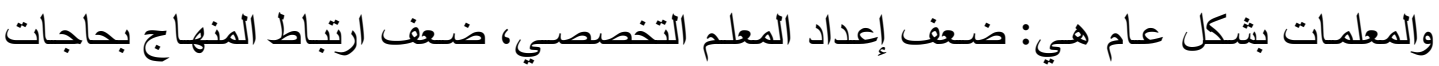
الطلبة، وسيطرة الجانب النظري وحشو المعلومات، التقيد التام بالمنهج التقليدي، ضعف دافعية التهية

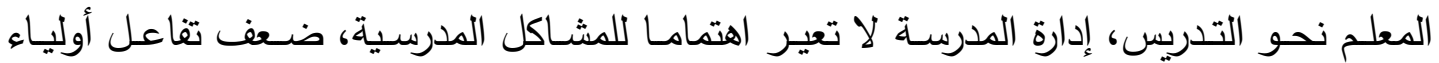

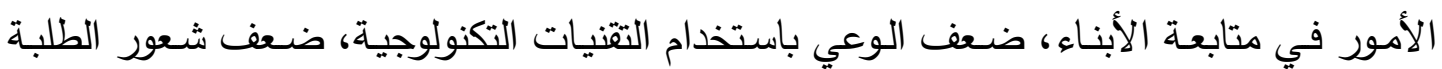
بالانتماء للمدرسة، وبالنسبة للمتغيرات الديمغرافية فقد كانت هتاك فروق دالة إحصائياً بين معلمي التعليم العام ومعلمي الطلبة ذوي الاحتياجات الخاصـة لصالح معلمي ذوي الاحتياجات الخاصـة،

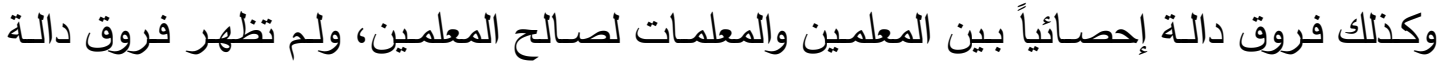
إحصائياً بين فئات الخبرة التدريسية، وتوصلت الدراسة لعدة توصيات من أهمها: مراجعة صحائف التخـرج الخاصــة بإعداد معلمي اللغـة العربيـة في كليـات إعداد المعلم وزيـادة المقررات العلميـة التخصصية والمتناسبة مع مناهج المرحلة المتوسطة، ورفع مستوى المعلمين في الجانبين العلمي والفني ببعض البرامج والدورات المتخصصـة، ومراجعة المناهج التعليمية وربطها بحاجات الطالب وحذف ما يمكن أن تحتويـه من معلومات غير ضرورية، وتثجيع المعلمين وزيـادة دافعيتهم نحو مهنة التدريس بحل مشاكلهم المهنية والعمل على تسهيل ما يواجههم من عقبات.

الكلمــات المفتــاحيــة: مشكلات معلمي اللغة العربية، التعليم العام، التربية الخاصـة.

$$
\begin{aligned}
& \text { (**) مدارس صعوبات التعلم- الكويت. } \\
& \text { (***) (**) (دارس التربية الخاصة - الكويت. } \\
& \text { (*****) مدارس الدمج في التعليم العام - الكويت. }
\end{aligned}
$$


The most important challenges the Arabic-language teachers may face while teaching to the middle stage students from the perspectives of teachers working in the public and private Education schools

\author{
Dr. Abuallah AI Ajami ${ }^{(*)}$ \& Khaled Al Ajami ${ }^{(* *)}$ \& Abdullah Al Ajami ${ }^{(* * *)}$
}

\title{
Ahstract $\square$
}

This study aims at discussing the most important and common challenges which the Arabic language male and female teachers face in the public and private education schools from their perspectives. It also aims at discussing the influence of the variables (gender of students and experience) on the presence of the problems included in the study tool, where the researchers used a scale of measurement which they prepared by themselves. The sample of the study consisted of 230 male and female teachers, selected randomly. The study reached some results and the most important of them may be as follows:

The challenges which face the male and female teachers in general are:

(1) The weak level of the mechanism used for preparing specialist teachers (2) The weak correlation between the curricula and the needs of the students. (3) The curriculum is dominated by the theoretical side and full of information stack. (4) The absolute strictness to the traditional methodology. (5) The teacher's weak motivation towards teaching. (6) The school management does not pay any attention to the school problems. (7) The weak interaction from the guardians in following up their children. (8) Lack of awareness in using the technological techniques. (9) The low feelings by the students towards belonging to the school.

As for the demographic variables, there are significant differences amongst the teachers of the public education schools and private

$\left({ }^{*}\right)$ Learning difficulties schools - Kuwait.

$\left({ }^{*}\right)$ Private education schools.

$\left(*^{* *}\right)$ Desegregation schools in public education- Kuwait. 
education schools for the teachers of disabled students. There are also significant differences amongst the male and female teachers for the male teachers. No significant differences appeared amongst the categories of educational experience.

The study concluded some recommendations the most important of them are:

- To consider the graduation papers related to preparing the Arabic language teachers in the faculties majored in preparing the teachers.

- To increase the specialized scientific curricula, to go in line with the curricula of the middle stage.

- To raise the scientific level of the teachers in the technical and scientific sides by some programs and specialized courses.

- To consider the educational curricula and make good ties amongst them and the needs of the students with omitting the unnecessary information in them.

- To encourage the teachers and increase their motivation towards the profession of teaching by solving their professional problems and working for facilitating the obstacles facing them.

Keywords: The challenges the Arabic-language teachers may face in the public and private Education schools. 


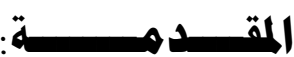

تعد مهنة التعليم من أنبل المهن، فهي مهنة الأنبياء، والعلماء ورثة الأنبياء، وتتطلع الأمم المتقدمـة إلى مـا يمكن أن يقدمـه المعلمون من إنثـاء جيل يترك أثاراً واضـحة في تقدم المجتمع، فالمعلم يدرس في اليوم الواحد عشرات الطلاب الذين يعول عليهم أن يكونوا عظماء المستقبل وقادته واطبائه ومهندسيه، فمهنة التدريس هي أساس كل المهن، فإن هيئة الظروف للمعلم استطاع أن يعطي وطاب قطف الثمرة، وإن خالط البيئة المدرسية صعوبات و مشكلات أثرت على الثمرة وقد تفسدها أو تقلل من جودتها، وحضـارة كل قوم وتقدمهم ينتقل عن طريق لغتهم، فاللغة أداة التلقي والتفكير بل هي التفكير نفسه في حال العمل فليس هناك فكر مجرد من غير رموز لغوية، وقد اكتشف بعض الباحثين المعاصرين علاقة كبيرة بين اللغة والموقف

$$
\text { السيكولوجي (الكندري سا ـ بـ) }
$$

تعـد المشكلات التعليميـة مـن الموضـوعات المـؤثرة سـلباً في أداء المعلـم ونفسيته أثثـاء ممارسته للعملية التعليمية "شأنها شأن معظم الظواهر النفسية كالقلق، والصراع، والإحباط، فهي من طبيعـة الوجـود الإنسـاني بحيث لا تخلو حياتــا مـن التوتر النـاتج عن المشكلات التي يواجههـا الانسان، ويختلف الأفراد في تعاملهم مع تلك المشكلات ونوعيتها ودرجة قوتها، وتثير البحوث إلى أن: "المدرسين يتعرضون أكثر من غيرهم للمشكلات بسبب ما تتسم بـه هذه المهنة من غموض الدور وكثرة المطالب المتعارضة، واستمرارية التعرض للمواقف الضاغطة" (المشعان، ... ؟؟). وبناءً على ذلك فإن الدور الفاعل الذي يقوم بـه المعلم في إنجاح العملية التعليمية، يتطلب منـه أن يكون في وضـع نفسي مريح بعيداً عن المشكلات والضـغوط التي تؤثر على الأداء المهني، ومن هذا المنطلق فإن المشكلات المدرسية التي يتعرض لها المعلم أثناء قيامه بعمله المهني لها تأثير كبير على إنتاجها وعطائه المهني، وفي حال استمرت هذه المشكلات المحيطة به فإن ذلك سيؤثر على أدائه وعلى فاعليته في أداء مهنة التدري.

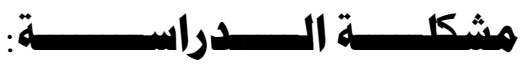

للمشكلات المدرسية اثر على المعلم وعلى مجتمع المعلمين، بـل وعلى حياة المعلم الداخلية والخارجيـة، ممـا يؤثر على أدائه وحياته اليوميـة وتحول دون تأديـة واجبه على أكمل 
وجه، وتزداد تلك المشكلات بحق المعلمين حيث اثبتت كثير من الدراسات العلمية ما يتعرض له المعلمين اثناء تدريسم من مشكلات مهنية وإدارية وضغوط نفسية تصل الى درجة الاحتراق Stacy Thomas النفسية، مما يدفع كثير من المعلمين لترك مهنة التعليم ويرى ستكي توماس

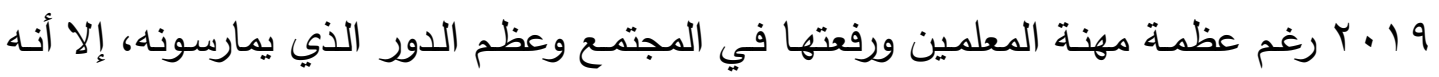
توجد صعوبات متعدة الجوانب ومتعددة الأشكال ومتجددة الظهور يواجهها المعلم في عمله، ويكون غير قادر على القيام بالاستجابات الملائمسة وتحقيق الهدف مما يسبب له توتراً وقلقاً، ويترك أثار سيئة على العملية التعليميّة. ويعد معلم اللغة العربية من اكثر المعلمين عرضـة للمشكلات الدراسية لما يحتاجه من جهد مضـاعف حيث أن المادة الدراسية هي لغتتا العربية وهي المرتكز الذي يعتمد عليه في تربية التلاميذ تربية متكاملة، فعن طريقها يؤدي المتعلم نشاطه التعليمي في المدرسة وخارجها،

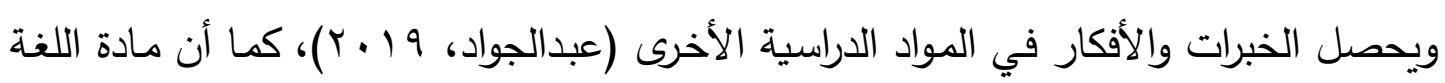
العربية ذات عمق في المحتوى والمهارات ترتبط بها كثير من الفروع مثل: النحو والبلاغـة

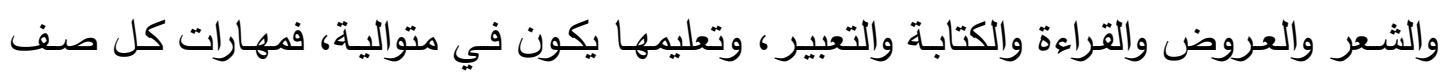
دراسي تعتمد على مهارات الصف الذي قبله، لتكون وحدة واحدة لا تتجزأ، وفي الجانب الإداري فلعل مادة اللغة العربية من أكثر المواد الدراسية حصص دراسية وتكاليف وأنشطة تحتاج جهد ومتابعة مستمرة من المعلم لمدى تعلم وإتقان الطلاب لما تعلموه، ومما يزيد مسئولية معلم اللغة العربية إذا كان معلماً للطلبة ذوي الاحتياجات الخاصة لما يحتاجونه من رعاية خاصة، ويمكن تلخيص مشكلة الدراسة في الأسئلة التالية: 1- مـا أهم المشكلات التي يعـاني منهـا معلمي ومعلمـات اللغـة العربيـة حسب متغيـرات

$$
\text { الدراسة الديمغرافية ( نوع الطلبة، الخبرة، الجنس ) ؟ }
$$

r- هل توجد فروق ذات دلالة إحصائية في المشكلات بين المعلمين حسب نوع الطلبة ؟ r- هل توجد فروق ذات دلالة إحصائية في المشكلات بين المعلمين حسب الخبرة ؟ ـ - هل توجد فروق ذات دلالة إحصائية في المشكلات بين المعلمين حسب الجنس ؟ 
الوقوف على أهم المشكلات وأكثرهـا شيوعاً للاى معلمي ومعلمات اللغـة العربية في التعليم العام والتربية الخاصـة من وجهة نظرهم، كما تهدف إلى أثر متغيرات كل من: ( نوع الطلبة، الخبرة، الجنس) على درجة وجود تلك المشكلات التي تضمنتها أداة الدراسة.

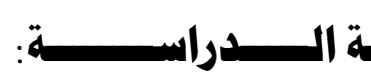

1-ندرة الدراسات على حد علم الباحثين التي أجريت في الكويت حول موضوع الدراسة

ومدى تأثره بمتغيرات الدراسة.

ץ- إثارة اهتمـام المختصـين مـن أكاديميين ومسؤولين عن العمليـة التربويـة نحو معلمي

ومعلمات اللغة العربية من خلال تفهم مشكلاتهم لتقديم البرامج العلاجية المناسبة.

r- تحديد المشكلات الطلابية، التي من شأنها إعاقة جهود المعلمين، بل وتعرقل عملية

التعلم، وتشغل بال المعلم والإدارة وأولياء الأمور •

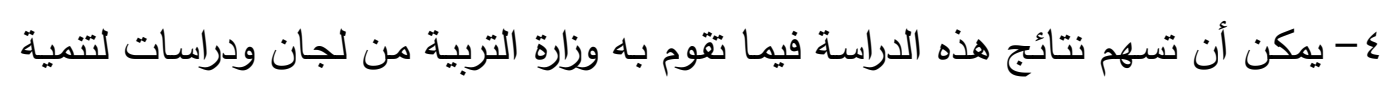

قدرات المعلمين وتوفير البيئة التعليمية السليمة.

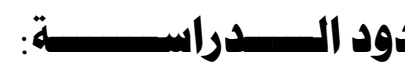

الحدود البثرية: طبقت على معلمي ومعلمات اللغة العربية في المرحلة المتوسطة.

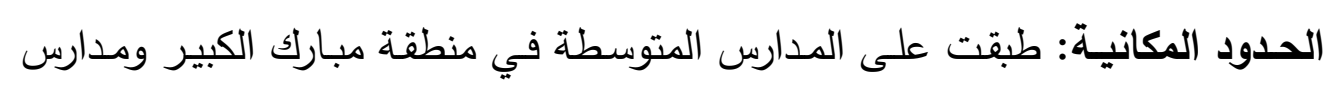
التربية الخاصة البنين والبنات.

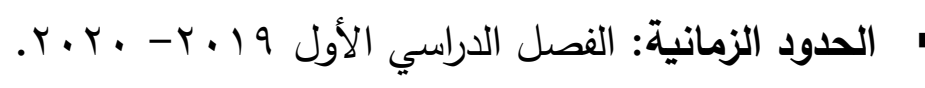

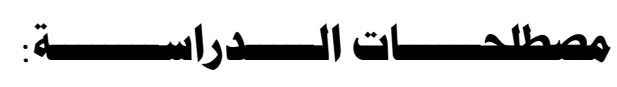

مشكلات معلمي اللغة العربية:

يقصد بها في الدراسة الحالية الصعوبات التي تواجه معلم اللغة العربية وتعيق أدائه وخاصة فيما يتعلق بالإدارة والمنهج ومع ذاته ومع الطلاب وأولياء أمورهم، وتعرف إجرائياً بأنها ما يقيسه مقياس مشكلات المعلمين المستخدم في الدراسة. 
يقصد بها في الدراسـة الحالية المدارس التي يدرس بها الطلبة العاديين، والمدمج في البعض منها طلبة من ذوي الاحتياجات الخاصة .

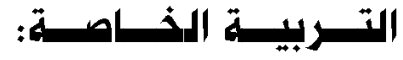

يقصد بها في هذه الدراسة المدارس التي يدرس بها طلبة من ذوي الاحتياجات الخاصـة سواء كانت معزولة عن التعليم العام أو فصول مدموجة في مدارس التعليم العام.

\section{الصعوبات التي تواجه المعلم:}

ويرى كل من: ستكي توماس Stacy Thomas 2019 وديريك ميدور 9 1. ب، و

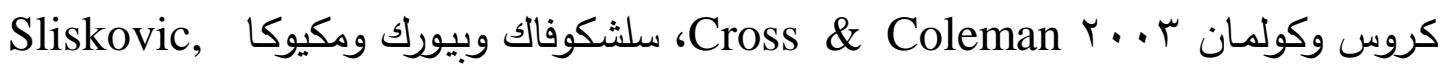
Buric, Macuka, 2017 والياسين، وفاء AL-Yaseen, Wafaa 2018 أن هناك العديد من الصعوبات التي يواجهها المعلم في التعليم يمكن اجمالها مع بعض مسبباتها فيما يلي: 1-بعض المجتمعات لا تقدر المعلم مما يؤثر سلباً في مكانته الاجتماعية، ويجعل الطلبة ينظرون للمعلم نظرة دونية .

ץ- عدم الاستقرار في أساليب التعليم وتغيرها الدائم الذي يجبر المعلم على تغيير طريقته في التدريس لمواكبة هذه التغيرات باستمرار، لذا فان جلب الاستقرار إلى الغرفة الصفية على الرغم من هذه التغيرات من أهم التحديات والصـوبات التي تواجـه المعلم في مهنته.

ب- ضعف الدعم الذي تقدمـه الإدارة للمعلمين، إلى جانب عدم توفر الموارد المناسبة التي

$$
\text { ترقى بالتعليم إلى المستوى المطلوب. }
$$

ع- نقص الحوافز والتقدير العام من قبل الطلاب والأهل والمدراء على حدٍ سواء. ه- يقف المعلم أمسام تحدي لعب أكثر من دور في آن واحد أثناء الحصـة الصفية، فهو معلم ومستشار ودليل وعامل اجتماعي وغيرها الكثير من الأدوار في ذات الوقت. 
צ- ضـيق الوقت وكثرة المهام التي يجب اسـتكمالها، مثل إنهـاء المسـتندات الورقيـة وعقد الاجتماعات بين المعلم والأهل وكتابة أوراق العمل والامتحانات وتصحيحها وعقد الفعاليات الرياضية والاجتماعية إلى جانب الحصص الدراسية والتعامل مع الطلاب والإدارة. - حاجة المعلم إلى تطوير قدراته الشخصية وتحديث مادته الدراسية بما يتناسب مع حاجة الطـلاب وابتكار أسـاليب تدريس جديدة وطـرق للتواصل مـع الطـلاب واكتشـاف نقاط الضعف والقوة لديهم وخلفياتهم المجتمعية وقياس تطورهم الأكاديمي. 1- عدم إيجاد التوازن بين الحياة الثخصية والعمل، إذ إن المعلم يضطر في غالبية الأيام للوصول إلى المدرسة مبكرًا ومغادرتها متأخرًا مع استكمال أعماله الورقية والتخطيط في المنزل. 9- التدني المعيشـي للمدرس لتدني راتبـه وحاجتـه إلى تحسين الوضـع المعاشـي، والذي يضمن لله التفرغ الوظيفي وعدم حاجته إلى أعمال أخرى ترهقه وتزيد من أعبائه. جمود المنهاج وثباته على نسق معين لمدة طويلة من الزمن. • 1-ضـف الدافع الداخلي للمعلم نحو العمل في مهنة التعليم، ولعل السبب في الانخراط في هذه المهنة هي الدوافع الخارجية مثل الراتب، أو القبول في الجامعة في تخصص ليس من رغباته الأولى.

ا ا-عدم وفرة الوسائل التعليميّة المناسبة، مما يضطر المعلم في الكثير من الأحيان إلى الإنفـاق مـن أموالـه الخاصـة في سـبيل جلب الهـدايا التحفيزيـة أو الاسـتثمار في أداة توضيحية أو أسلوب دراسي جديد.

ب ا-البحث المستمر عن طرق تتناسـب ومستويات مختلف الطـلاب في الغرفـة الصـفية الواحدة، ويتطلـب ذلك المراقبـة والاسـتنتاج واسـتخدام المعلومـات المتاحـة والمصـادر المختلفة، مما يستهلك وقت المعلم وجهده داخل الصف وخارجه. ب ا-يسـى الأهـل إلى التركيز على سـلبيات العمليـة التعليميـة وأخطـاء المعلـم في حـال وجودها مع التغاضي عن الإيجابيات.

ء ا-صـعوبة التعامـل مـع سـلوكيات الطـلاب على اخـتلاف بيئـاتهم وخلفيـاتهم الطبقيـة والاجتماعية والعائلية والتربوية. 
ه ا- التعامل مع الطالب يستهلك طاقة المعلم ويتطلب الكثير من الوقت والجهد الفردي من قبله إلى جانب الذكاء العاطفي والاجتماعي من طرفه. 7 ا-يشكل الفساد القيمي والأخلاقي عند قسم كبير من الطلاب مشكلة كبيرة لدى المعلم في محاولة إيجاد طرق للتعامل معها. I ا - عدم تفاعل الطلاب في المشاركة في الحصص الصفيّة. 1 ا - عدم متابعـة الأهل لأبنـائهم في المدرسـة، أو ضـفف هذه المتابعـة، وضـف التواصل الإيجـابي بين المجتمـع المحلي والمدرسـة، وذلك نظرًا إلى ثانويـة النظرة للتعليم عند

$$
\text { معظم الأهل. }
$$

9 ا-فسـاد البيئة التي ينشـأ فيها الطـلاب، وفسـاد الحصـن التربوي الأول لهم والمتمثل في أسرهم، مما يترك آثاره على سلوكهم في المدرسة. • ץ-نظرة الأهل للتعليم بنظرة ثانويّة، وهذا ينعكس على الطلاب واهتمامهم بالتعليم إلى جانب عدم انخراط جميع الأهل في العملية التعليمية وعدم تحفيز أولادهم على التعلم والنجاح. ا ب-حاجـات ومشكلات الطلبة المتفوقين لمـا لهم من متطلبات وقدرات يحتاج المعلم أن

$$
\text { يلبيها ويتواكب مع سرعة تغيرات القدرات العقلية. }
$$

r ب-ضـغوط الحرمان العاطفي والوجداني والحرمان من أحد الوالدين أو كليهما أو انشغال

$$
\text { الوالدين عن أولادهما. }
$$

سץ-عدم قيام ولي الأمر بدوره تجاه متطلبات المدرسة في متابعة أبنه. ع ب-قلـة عـدد الحصـص المخصصـة للمـادة الدراسـية، وفقـر الكتـاب المدرسـي للعناصـر الأساسية، وعدم الاتصال بالحياة اليومية، وفقر الأدوات والتقنيات المستخدمة.

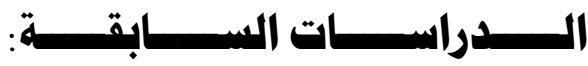

دراسـة إبراهيم، على 9 ـ ـ والتي هدفت لمعرفة الصعوبات التي تواجـه تدريس مـادة الأحياء في المرحلة الثانوية في منطقة العاصمة بدولة الكويت، وتكونت عينة الدراسة من ؟ـ معلم ومعلمـه، وتوصلت لعدة نتائج من أهمها: أن أكثر المجالات صعوبة كانت ذات الصلة 
بمعلم مادة الأحياء، يليها صعوبة ذات الصلة بالكتاب المدرسي، وتثير النتائج إلى وجود فروق ذات دلالة تعزى إلى النوع والمؤهل العلمي، وعدم وجود فروق ذات دلالة تعزى لسنوات الخبرة . دراسة عقيل والعنزي والمنصوري(9 1 • ب) هدفت الدراسة ألى تحديد مدى توافر الكفايات المهنية لمعلمات الرياضيات في المرحلة الابتدائية في ضوء معايير (NCTM) من وجهة نظر رؤساء أقسـامهن إضـافة إلى أثر بعض المتغيرات الديمغرافيـة أحريت الدراسـة علَ ( رياضيات قمن بتقييم (0 (1) معلمة رياضيات تحت إشرافهن، وتوصلت الدراسة إلى عدة نتائج من أهمها: انخفاض مستوى تقييم الكفايات المهنية خاصة في مجال التنفيذ والتقييم. دراسة السبر ، حمد (1 ( • ب) والتي هدفت للتعرف على الصعوبات التي يواجهها معلمو اللغــة العربيـة في تدريس مقـرر الكفايـات اللغويـة في المرحلـة الثانويـة في المملكـة العربيـة السعودية، من خلال المتغيرات التالية (التأهيل الأكاديمي، التدريب، الخبرة التدريسية) وتوصلت الدراسة إلى عدة نتائج من أهمها: أن معلمي اللغة العربية يواجهون صعوبات في تدريس مقرر الكفايات اللغويـة في المرحلة الثانويـة وجاء ترتيب أهم تلك الصـوبات كمـا يلي: (الصسوبات المتعلقـة بطـرق التـدريس، الصـعوبات المتعلقـة بتقويم الكفايـات اللغويـة، الصـعوبات المتعلقـة بمحتوى الكفايـات اللغوية(النصـوص - الأنثـطة والتـدرببات، ثم جـاءت الصـعوبات المتعلقـة بالكفايات اللغويـة)، وقد أشـارت نتائج الدراسـة إلى عدم وجود فروق ذات دلالة إحصـائية بين تقدير معلمي اللغـة العربيـة لجميع الصـعوبات في تدريس مقرر الكفايات اللغويـة في المرحلـة الثانوية وفقاً للمتغيرات التالية ( المؤهل الأكاديمي- التدريب - الخبرة التدريسية). دراسـة سلشكوفاك وبيورك ومكيوكا Sliskovic, Buric, Macuka, 2017 والتي هدفت إلى التعرف على اتجاهات المعلمين نحو مهنة التعليم في كرواتيا، وطبقت المنهج الكيفي عن طريق مقابلة مب معلم، وتوصلت لعدة نتائج من أهمها: وجود ضغوط مهنية على المعلمين وعدم تقديرها من قبل المجتمع، كما أن المعلمين يواجهون صعوبات تتعلق بالطلبة وظروف العمل وأولياء الأمور والنظـام التربوي بشكل عـام، وتشكل المكانـة الاجتماعيـة للمعلم والنظـام التربوي التعليمي مصدران لاتجاهات المعلمين السلبية نحو مهنة التعليم. 
دراسة الحميضـ V V ا ب والتي هدفت إلى التعرف على أبرز الشككلات التي تواجه معلمي

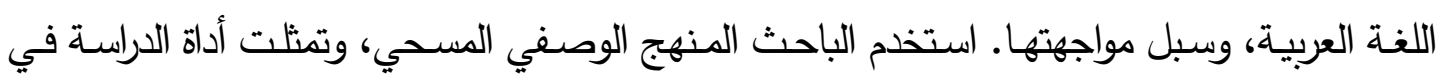

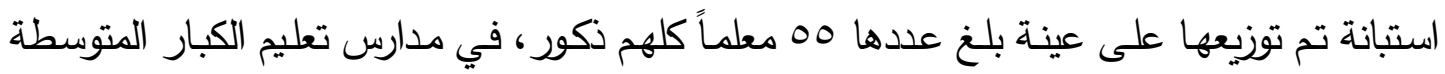

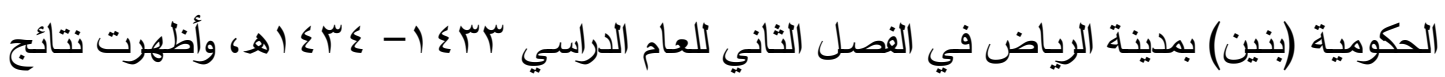

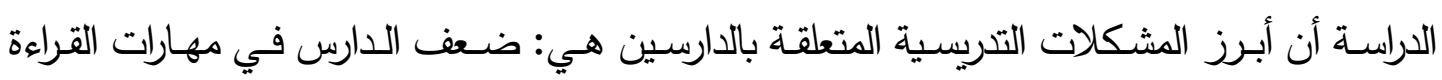
والكتابة، التزامات الدارس الأسرية لا تساعده على المذاكرة. وأن أبرز المشكلات المتعلقة بالمناهج هي: عدم وجود مناهج مخصصة للدارس الكبير، وعدم مشاركته في اختيار مناهجها، وعدم تطورها وتغيرها باستمرار، أو عدم مناسبتها الوقت المحدد لإتمامها. وأن أبرز المشكلات المتعلقة بالبيئة هي:

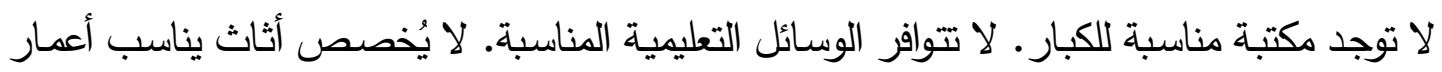
الدارسين. عدم وجود مركز مصادر تعلم ومبنى خاص بها. عدم وجود فروق ذوات دلالة إحصائية

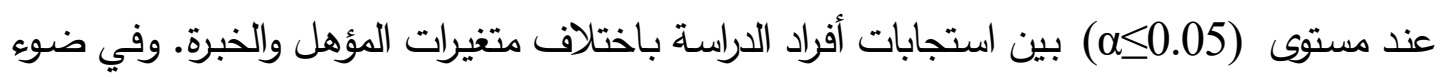

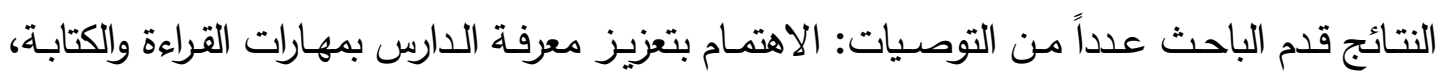

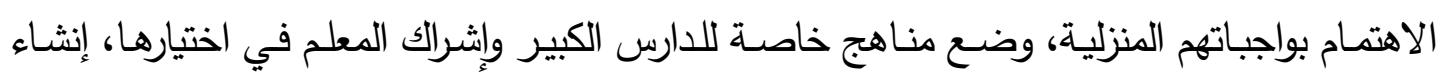
مكتبة مناسبة للكبار وتوفير الوسائل التعليمية المناسبة، فتح وإنثاء مراكز مصادر التهاه التعلم. دراسة بوزدوجان وأوزجلو 2015 Bozdogan \& Uzoglu والتي هدفت لمعرفة آراء معلمي

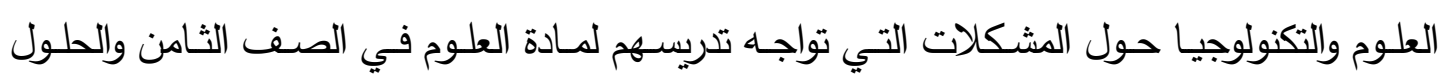

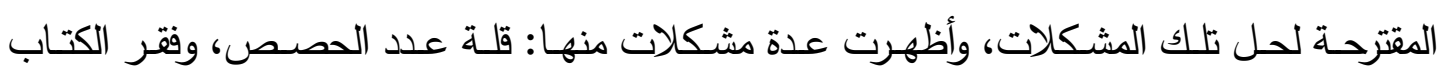
المدرسي للعناصر الأساسية، وعدم الاتصال بالحياة اليومية، وفقر الأدوات والتتنيات المستخدمة.

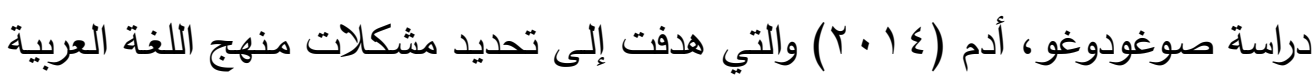
بالمدارس الثانوية الحكومية في جمهورية مالي، وتوصل الباحث إلى عدة نتائج من أهمها: 1- عدم تدريب المعلمين على استخدام الوسائل الحديثة.

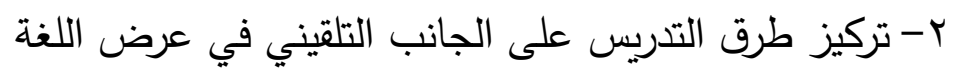
r- عدم اشتمال الكتاب المقرر على وسائل تعليمية مناسبة. ـ - كثرة الأعباء على المعلم تحد من التنويع في طرق تدريس اللغة العربية. 0- عدم وجود معامل لغوية تساعد في تتمية اللغة. 
دراسة السلطان، عبدالمحسن (§بـ ا هجري) والتي هدفت إلى تقويم أداء معلمي اللغة

العربية في المرحلة الابتدائية بمحافظة الاحسـاء في ضـوء معايير الجودة الثـاملة، وتوصلت الدراسـة إلى عدة نتائج من أهمها: التوصل إلى قائمسة بمعايير الجودة الثاملة اللازمة لمعلمي اللغة العربية في المرحلة الابتدائية بلغ عددها سبع وخمسين عبارة، أن مستوئ أداء معلمي اللغة العربية للمحاور (تخطيط الدرس، والتمكن من المادة العلمية، والاستراتيجيات التدريسية، والإدارة الصفية، والتقويم) قد تحقق بدرجة كبيرة .

دراسة لال وشيرجل Lal \& Shergill 2012 والتي هدفت لمعرفة مدى رضا المعلمين واتجاهاتهم نحو التعليم كمهنـة في بنجـاب وهريانـا في الباكستان، وتوصلت الدراسـة إلى عدة نتائج من أهمها رضا المعلمين والمعلمات عن مهنة التدريس ولا يوجد فروق تعزى للجنس . دراسة عطيف، يحيى (Y I † Y) هدفت الدراسة إلى معرفة أبرز مشكلات تدريس مقرر "لغتي الخالدة" للصف الأول المتوسط وفق تصورات مشرفي اللغة العربية ومعلميها، وتوصلت

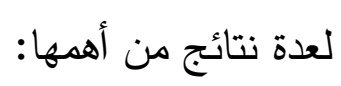
ضـف تركيز الكفايات المستهدفة في المقرر على المجالات المهاريـة والوجدانية يحد من قدرة المعلم على التكيف مع مواصفات المهارة التدريسية وأسسها النغسية والتربوية. الأنشطة الواردة في المقر لا تساهم في توظيف العمل الجماعي لدى التلاميذ. أنواع التقويم المستخدمة في المقرر لا تشمل أنواع من التقويم مثل (القبلي، البنائي، التشخيصـي، النهائي) ممـا لا يعطي المعلم صـورة واضـحة عـن مستوى طلابـه في امتساب الكفايات المستهدفة.

ضـعف الإعـداد التخصصـي لـبعض المعلمـين يضـعف قدرتهم على تـدريس بعض

$$
\text { مكونات وحدات المقرر • }
$$

ضعف الإعداد التربوي لبعض المعلمين يؤثر في كفاية التدري لايهم.

دراسـة العجمي والعجمي r ا ـ ب والتي هدفت لمعرفة أهم مصـادر الضـغوط المهنية التي تواجـه معلم التربيـة الخاصــة، ومعرفـة الفـروق بـين تلـك الضـغوط عنـــ المعلمـين بحسب بعض 
المتغيرات الديمغرافية، وتوصلت الدراسة لعدة نتائج من أهمها: أن من أهم مصادر الضغوط المهنية لمعلمي التربية الخاصـة: عدم وجود دراسية مناهج مناسبة، التباين بين مستويات الطلبة المعاقين، زيادة عدد الطلاب في الفصول، التوقعات العالية من ولي الأمر، زيادة عدد حصص المعلمين، ضعف الراتب الثهري، ضعف التقدير من قبل المسئولين، ضعف الدافعية عند الطلاب.

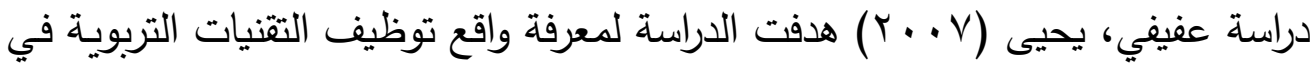
تدريس اللغة العربية في المرحلة الثانوية من وجهة نظر مديري المدارس الثانوية ومعلمي اللغة العربية في منطقة عسير التعليمية، وتوصلت الدراسة إلى عدة نتائج من أهها: أن المدارس لهارئه تفتقر إلى توافر التقنيات التربوية المناسبة لتدريس اللغة العربية،، وأن ذلك غير مرض لعيد لعينة الدراسة، كما بينت النتائج أهمية التقنيات في تدريس اللغة العربية من وجهة نظر عينة الدراسة، ومن المعوقات التي تعوق استخدام التقنيات: المبنى المدرسي، انخفاض الوعي بأهمية استخدام التقنيات بالنسبة للمعلمين والإدارة. دراسـة النصـار، محمد عبدالعزيز (דr I 1 هـ) والتي هدفت لمعرفة واقع أداء معلمي اللغة العربية من المتخصصين وغيرهم في الصفوف الأولية في المدارس الحكومية في الرياض، وتوصلت الدراسة لعدةر نتائج من أهمها:

أن معلمي اللغـة العربية عموماً المتخصصين في اللغـة العربيـة وغير المتخصصين نتمكنون في أدائهم اللغوي (قراءة وكتابة ومحادثة) بدرجة ضعيفة . أن معلمي اللغـة العربية في الصفوف الأوليـة المتخصصين في اللغـة العربية وغير المتخصصين متمكنون في مجال القراءة والمحادثة بدرجة متوسطة . أن معلمي اللغـة العربية في الصفوف الأوليـة المتخصصين في اللغـة العربية وغير المتخصصين متمكنون في مجال الكتابة بدرجة ضعيفة. وجود فروق دالة إحصائياً بين المعلمين المتخصصين في اللغة العربية وغير المتخصصين فيها في جميع المجالات اللغوية لصالح المعلمين المتخصصين في اللغة العربية . 
عدم وجود فروق دالة إحصائياً تعزى لمتغير سنوات الخبرة بين المعلمين المتخصصين

$$
\text { في اللغة العربية وغير المتخصصين فيها. }
$$

عدم وجود فروق دالـة إحصـائياً بين المعلمين المتخصصين في اللغـة العربية وغير

$$
\text { المتخصصين فيها تعزى إلى متغير الصف الدراسي. }
$$

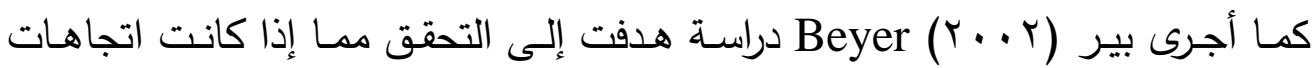
الأهالي, والمعلمين العاديين, ومعلمي التربية الخاصة, والمديرين تختلف باختلاف نموذج الدمج للتلاميذ غير العاديين في مدرسة سلفر فالي الثانوية بولاية كاليفورنيا الأمريكية. وقد كانـت العينـة التهي تم اختيارهـا لهـذه الدراسـة تشـتمل على الأهـالي, والمـديرين, والمعلمين العـاديين, ومعلمي التربيـة الخاصــة الذين يعهـون مـع التلاميذ غيـر العـاديين في المدرسة, وقد تم الحصول على البيانات من العينـة للتعرف على اتجاهاتهم نحو وضع التلاميذ غير العاديين في الصفوف العادية والأثر الذي يحدثه في المدرسة. وقد أثارت نتائج الدراسة إلى أن هناك اختلافاً في الاتجاهات التي عبر عنها المعلمون العاديون ومعلمو التربية الخاصـة فيما يتعلق بمفهوم دمج التلاميذ غير العاديين , حيث أظهر المعلمون العاديون اتجاها ايجابيا نحو الدمج, في حين أظهر معلمو التربية الخاصة اتجاها سلبيا. أما الفروق بين الأهالي والمديرين فقد كانت قليلة جداً نحو التلاميذ غير العاديين, وإذا ما كان هناك فرق بسيط فقد كان ذلك في الاتجاه نحو مفهوم الدمج.

\section{التحليق على اللاراسات السابقة:}

ركزت الدراسـات السـابقة على عدة نقاط من أهمها: اتجاهات وأراء المعلمين حول بعض

المواضيع مثل: تقويم الأداء وتقويم الكفايات، وتتاول بعض منها مـا يواجه المعلمين من ضـوط مهنية أو صعوبات ومشكلات في بعض المواد مثل الأحياء والعلوم والتكنولوجيا وغيرها، وتتاولت

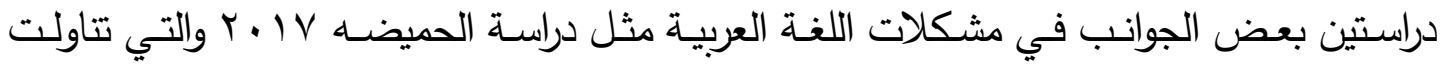
مشكلات اللغة العربية في مدارس تعليم الكبار ودراسـة السبر 1 1 • بوالتي درست مشكلات اللغة العربية في المرحلـة الثانويـة، ،كلتيهما في مدينـة الرياض في المملكة العربيـة السعودية، ممـا سبق 
يتبين أهمية هذه الدراسـة وخاصـة أنها حددت البحث في مشكلات معلم اللغـة العربية في المرحلة المتوسطة في التعليم العام ومدارس التربية الخاصـة في الكويت، والتي تحتاج إلى وقفة تعرف على أهم تلك المشكلات وتحديدها بشكل دقيق، ومحاولة وضع الحلول لها، وتتبيه المسئولين عليها.

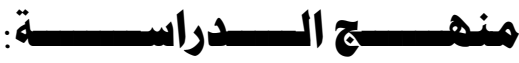

اتبعت الدراسة المنهج الوصفي المقارن، حيث هدفت إلى البحث عن أهم المشكلات وأكثرها شيوعاً لدى معلمي اللغة العربية في التعليم العام والتربية الخاصة من وجهة نظرهم، كما تهدف إلى معرفة أثر متغيرات الدراسة.

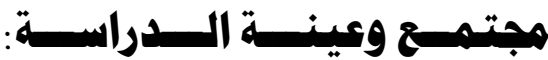

تكـون مجتمـع الدراسـة مـن جميع معلمي اللغــة العربيـة في المرحلـة المتوسطة بدولـة

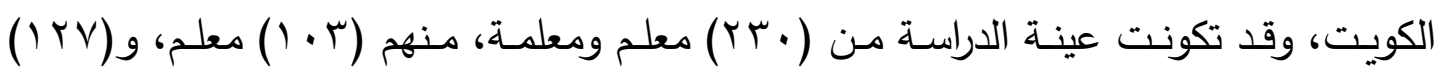

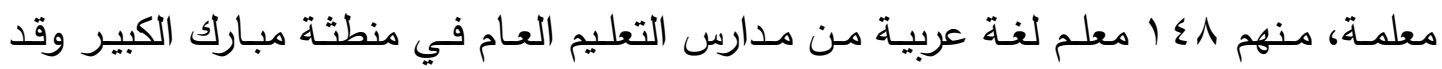
أختيـرت منطقـة مبـارك الكبير بطريقـة عشوائية مـن بـين سـتة منـاطق تعليميـة في الكويـ، ومنهم 1 معلم ومعلمة لغة عربية تم اتختيارهم بطريقة عمدية، حيث لا يوجد غيرهم في الكويت وهم معلمي مدارس التربية الخاصـة في حولي، ومعلمي مدارس صعوبات التعلم المستقلة عن التعليم العام، وفصول بطء التعلم المدمجة في مدارس التعليم العام وعددها با مدرسة في كل منطقة تعليمية مدرستين متوسطة مدرسة للبنين ومدرسة للبنات.

\section{مقياس مشكلات المعلميز:}

استخدم الباحثون مقياساً من تصميمهم لقياس مشكلات المعلمين ويطبق على الأفراد منفصلين أو بشكل جماعي، كما أنه غير موقوت بزمن. 
1-جمع المعلومات: تم جمع عبارات المقياس عن طريقين هما:

أ) توزيع . . ( استبانة جمع منها VT استبانة على مجموعة من المعلمين والمعلمات،

حيث احتوت الاستبانة على سؤال مؤداه : ما المشكلات التي تتعرض لها كمعلم لغة عربية؟ وبعد فرزها اختير منها ·. ع عبارة حصلت على أعلى تكرار •

ب) الرجوع لبعض المقاييس المتوافرة في الأدب التربوي السـابق والمطبقة على البيئة العربية، اختار الباحثين منها 0 اعبارة .

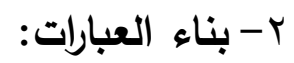

أ) حـاول البـاحثون فـي بنــاء العبـارات أن تكــون جديــدة فـي تركيبهــا (قـدر

$$
\text { الإمكان) وفي إيجازها. }
$$

ب) قام الباحثون بتصميم المقياس من هب بنداً موزعة بالتساوي على أبعاد المقياس (مشـكلات الاداريـة، مشكلات في المـنهج، مشـكلات طلابيـة، مشـكلات ذاتيـة،

$$
\text { مشكلات أولياء الأمور)، لكل بعد V بنود . }
$$

r- عرض المقياس على خمسـة من المحكمين المختصين في المناهج وطرق التدريس والتربية الخاصة، وتمت موافقتهم على صـلاحية المقياس بعد إجراء بعض التعديل في صياغة بعض العبارات. ع - تقنين المقياس: قام الباحثون بتطبيق المقياس بهدف حساب معاملات صدقه وثباته على عينـة عشوائية من المعلمين والمعلمات في المرحلة المتوسطة، وبلِغ أفراد العينة • ع معلماً ومعلمة، وبعد التطبيق قام الباحث بإدخال البيانات في الحاسب الآلي، ومن ثم قام باستخدام التحليل العاملي للتأكد من أبعاد المقياس، حيث تم إدخال بنود كل بعد على حده، وقد قام الباحث في هذه المرحلة باستبعاد ^ بنود من أصل هب بنداً كانت تشبعاتها في جميع الأبعاد أقل من (r, ·)، وقد تم استبعاد بندين من كل من بعدي المشكلات الإداريـة والذاتيـة، وبنـد مـن بعد المشكلات الطلابيـة، وثلاثـة بنـودمن بعد مشكلات أولياء الأمور ، لتصبح بنود المقياس V ب بنداً موزعة على أبعاد المقياس، كما 
يلي: ؛ بنـود لبعد مشكلات أولياء الأمسور ، وخمس بنـود لكل مـن بعدي المشكلات

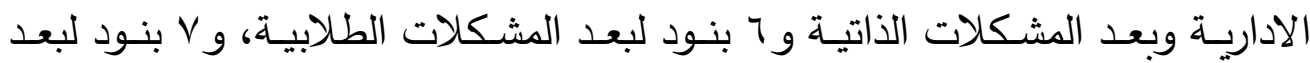

$$
\text { مشكلات منهج وطرق التدري. }
$$

0- تصحيح المقياس: بلغت الدرجة الكلية للمقياس هبا درجة، وبلغت أقل درجة للمقياس

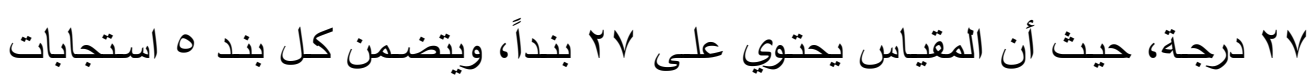
يتراوح تقدير الدرجة لتلك الاستجابات من درجة إلى خمس درجات. צ- صدق وثبات المقياس:

أولاً: صدق المقياس: استخدم الباحث في حساب الصدق: أ) صدق المحكمين: عرض الباحثون المقياس في صورتيه الأولية والنهائية على خمسة محكمين من ذوي الاختصـاص في التربية ومناهج وطرق التدريس، وتم إجراء بعض التعديل في صياغة بعض العبارات في التحكيم الأول، وفي التحكيم الثاني تم اعتماد اتفاقهم بدرجة ، ^ ٪ كدرجة مقبولة للموافقة على كل بند . ب) صـدق الاتسـاق الـداخلي: قـام البـاحثون بحسـاب صـدق الاتسـاق الـاخلي بـين بنـود المقياس بعضها البعض، حيث تراوحت معاملات الارتباط بين (ع بس, • ) و (7 • 0, •)، وقد كانت جميعها دالة إحصـائياً عند مستوى ( • ( •) وهذا يدل على أنه يوجد هناك اتساق بين بنود المقياس والدرجة الكلية للمقياس، وبالتالي يدل على أن المقياس يتمتع

$$
\text { بدرجة صدق مقبولة. }
$$

ثانياً: ثبات المقياس: استخدم الباحث لقياس ثبات المقياس: أ) معادلة ثبات ألفا كرنباخ، والجدول التالي يبين معاملات الثبات:

\begin{tabular}{|c|c|}
\hline ألف لــــــــا & البعــــــــــلـ \\
\hline$\cdot, T I r$ & مشكلات إداريـة \\
\hline$\cdot, 7 \leqslant \leqslant$ & مشكلات في المنهج \\
\hline$\cdot, 09 r$ & مشكلات طلابية \\
\hline$\cdot, 7 \wedge$. & مشكلات ذاتية \\
\hline$\cdot, 007$ & مشكلات أولياء الأمور \\
\hline
\end{tabular}
جدول رقم (1) معاملات ثبات المقياس بطريقة ألفا كرنباخ 
كما قام الباحثون باستخراج معامل ألفا كرنباخ حيث بلغ معامل الثبات الكلي للمقياس ا 1, ، ، وهذا يدل على أنه يتمتع بثبات عال.

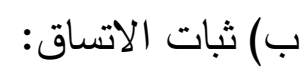

والذي يعنـي مـدى ارتبـاط درجـة الأبعـاد الفرعيـة للمقيـاس بالدرجـة الكليـة للمقيـاس،

والجدول التالي يبين معاملات الاتساق للأبعاد الفرعية للمقياس.

جلدول رقم (ץ) صلد الاتساق لمقياس المشكلات الطلابية

\begin{tabular}{|c|c|c|}
\hline مستوى الدلالة & معامل الاتساق الداخلي & البعد \\
\hline$\cdot, \cdots 1$ & $\cdot, 7 \vee 0$ & مشكلات إداريـة \\
\hline$\cdot, \cdots 1$ & $\cdot, 770$ & مشكلات في المنهج \\
\hline$\cdot, \cdots 1$ & $\cdot, 701$ & مشكلات طلابية \\
\hline$\cdot, \cdots 1$ & $\cdot, 7 \wedge \wedge$ & مشكلات ذاتية \\
\hline$\cdot, \cdots 1$ & $\cdot, T \vee V$ & مشكلات أولياء الأمور \\
\hline
\end{tabular}

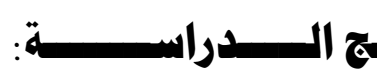

للإجابة على أسئلة الدراسة التالية:

1- ما أهم المشكلات التي يعاني منها معلمي ومعلمات اللغة العربية في المرحلة المتوسطة

$$
\text { حسب متغيرات الدراسة الديمغرافية (نوع الطلبة، الخبرة، الجنس)؟ }
$$

ץ- هل توجد فروق ذات دلالة إحصائية في المشكلات بين المعلمين حسب نوع الطلبة؟ ץ- هل توجد فروق ذات دلالة إحصائية في المشكلات بين المعلمين حسب الخبرة؟

\section{الســــــوال الأول:}

مـا أهـم المشكلات التـي يعـاني منهـا معلمسي ومعلمـات اللغــة العربيـة في المرحلـة

المتوسطة حسب متغيرات الدراسة الايمغرافية (نوع الطلبة، الخبرة، الجنس)؟

للإجابة على السؤال السـابق، قام الباحثون باستخدام فترة الثقة لتحديد أهم المشكلات

التي تواجه معلمي ومعلمات اللغة العربية في المرحلة المتوسطة، حيث قام بحساب فترة الثقة

وتوزيعها على أربعة فترات كالتالي: 
جلول رقم (ץ) فتزة الثقة بالنسبة لمستوى المشكلات

\begin{tabular}{|c|c|}
\hline فــــــة الثقــــــة & مستــــــــ المشكـــــلات \\
\hline $1,10-\cdot, 0$ & غير مهمة \\
\hline$r, \ldots-1, \vee\urcorner$ & متوسطة الأهمية \\
\hline$\varepsilon, r_{0}-r, \cdot 1$ & مهمة \\
\hline $0,0-\Sigma, Y\}$ & بالغة الأهمية \\
\hline
\end{tabular}

بعد تحديد مستوى المشكلات فإن الباحثون سوف يعتبرون بنود المقياس التي تقع في فترتي مهمة وبالغة الأهمية هي أهم المشكلات التي تواجها معلمي ومعلمات اللغة العربية في المرحلة المتوسطة بحسب متغيرات الدراسة التالية:

\section{أولا : مشكلات المعلمين بشكل عام :}

لمعرفة أهم المشكلات التي تواجه معلمي ومعلمات اللغة العربية في المرحلة المتوسطة بشكل عام، قام الباحثون باستخراج المتوسطات الحسابية والانحرافات المعياريـة لبنود المقياس بالنسبة لعينة الدراسة كاملة، والجدول التالي يبين ذلك: جلول رقم (§) المتوسطات الحسابية والانحرافات المعيارية لبنود المقياس بالنسبة لعينة الدراسة بشكل عاه

\begin{tabular}{|c|c|c|c|c|}
\hline نـــوع المشكلـــــة & $\varepsilon$ & هر & المشك & مر \\
\hline ذاتي & $1, \leqslant Y$ & r, TV & ضعف إعداد المعلم التخصصي & 1 \\
\hline المنهج وطرق التدريس & 1,0 r & r,o & سيطرة الجانب النظري وحشو المعلومات & r \\
\hline المنهج وطرق التدريس & $1, \varepsilon \wedge$ & 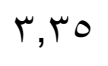 & ضعف ارتباط المنهاج بحاجات الطلبة & r \\
\hline 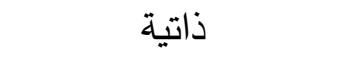 & 1,0 & 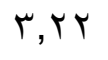 & ضعف دافعية المعلم نحو التدريس & $\varepsilon$ \\
\hline 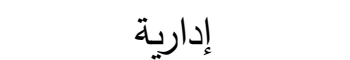 & 1,00 & $r, r \cdot$ & إدارة المدرسة لا تعير اهتماما للمشاكل المدرسية & 0 \\
\hline المنهج وطرق التدريس & $1,0 \mathrm{~V}$ & r, 10 & التقيد التام بالمنهج التقليدي & 7 \\
\hline أولياء الأمور & 1,01 & 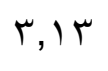 & ضعف تقاعل أولياء الأمور في متابعة الابناء & V \\
\hline 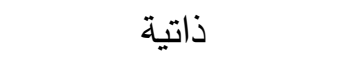 & 1,00 & $r, 9$ & ضعف الوعي باستخدام التقنيات التكنولوجية & $\wedge$ \\
\hline 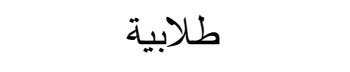 & 1,09 & 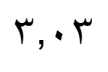 & ضعف شعور الطلبة بالانتماء للمدرسة & 9 \\
\hline
\end{tabular}


لمعرفـة أهم المشكلات التي تواجـه المعلمين والمعلمـات بحسب نـوع الطلبـة (الطلبـة

$$
\text { العاديين - الطلبة ذوي الاحتياجات الخاصة) }
$$

قام الباحثون بدايةً باستخراج المتوسطات الحسابية والانحرافات المعياريـة لبنود المقياس للذكور ، والجدول التالي يبين ذلك: جلول رقم (0) المتوسطات الحسابية والانحرافات المييارية لبنود المقياس بالنسبة للمعلمين الذين يلدرسوز الطلبة العاديين

\begin{tabular}{|c|c|c|c|c|}
\hline نـوع الششكلــة & $\varepsilon$ & مر & 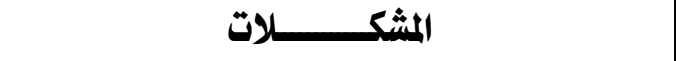 & 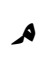 \\
\hline 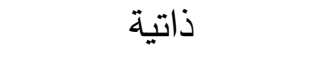 & $1, r \varepsilon$ & r, & ضعف إعداد المعلم التخصصي & 1 \\
\hline المنهج وطرق التدريس & $1, r V$ & r,ov & سيطرة الجانب النظري وحشو المعلومات & $r$ \\
\hline المنهج وطرق التدريس & 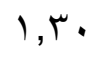 & $r, 0$. & ضعف ارتباط المنهاج بحاجات الطلبة & r \\
\hline أولياء الأمور & $1, r q$ & 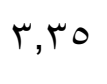 & ضعف تفاعل أولياء الأمور في متابعة الابناء & $\varepsilon$ \\
\hline 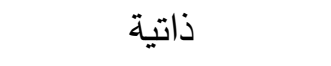 & $1, \mathrm{rV}$ & $r, i v$ & ضعف الوعي باستخدام التقنيات التكنولوجية & 0 \\
\hline 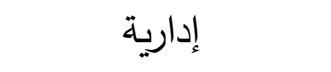 & 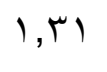 & $r, 1 \cdot$ & |إدارة المدرسة لا تعير اهتماما للمشاكل المدرسية & 7 \\
\hline 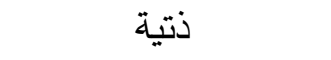 & $1, r \varepsilon$ & $r, \tau$ & ضعف دافعية المعلم نحو التدريس & V \\
\hline طلابية & 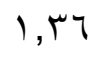 & $r, r$ & ضعف شعور الطلبة بالانتماء للمدرسة & $\Lambda$ \\
\hline المنهج وطرق التدريس & $1, \varepsilon$ & $r, \cdot 1$ & |التقيد التام بالمنهج التقليدي & 9 \\
\hline
\end{tabular}

ثم قام الباحثون باستخراج المتوسطات الحسابية والانحرافات المعياريـة لبنود المقياس للإناث، والجدول التالي يبين ذلك: 
جلول رقم (7) المتوسطات الحسابية والانحرافات المعيارية لبنود المقياس

بالنسبة للمعلمين الذين يلدرسون الطلبة ذوي الاحتياجات الخاصة

\begin{tabular}{|c|c|c|c|c|}
\hline نوع المشكلة & $\varepsilon$ & هـ & المكلات & هـ \\
\hline 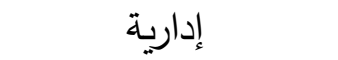 & $1, r_{0}$ & $r, v r$ & |إدارة المدرسة لا تعير اهتماما للمشاكل المدرسية & 1 \\
\hline المنهج وطرق التدريس & $1, r V$ & r, 70 & |ضعف ارتباط المنهاج بحاجات الطلبة & r \\
\hline ذاتية & $1, r \cdot$ & $r, \tau$. & ضعف الوعي باستخدام التقنيات التكنولوجية & r \\
\hline المنهج وطرق التدريس & $1, r \varepsilon$ & r,or & |سيطرة الجانب النظري وحشو المعلومات & $\varepsilon$ \\
\hline المنهج وطرق التدريس & $1, r v$ & $r, 0$. & |المناهج تركيز على طرق التدريس التقليدية & o \\
\hline ذاتية & $1, \varepsilon$. & $r, \varepsilon \varepsilon$ & ضعف دافعية المعلم نحو التدريس & 7 \\
\hline المنهج وطرق التدريس & $1, \varepsilon V$ & r, ro & ضعف دور الموجهين نحو المعلمين & V \\
\hline طلابية & $1, \varepsilon \wedge$ & 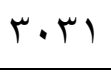 & |قدرات الطلاب أقل من مستوى المواد الدراسية & $\wedge$ \\
\hline طلابية & $1, \varepsilon r$ & $r, r \cdot$ & ضعف اعتماد الطالب على نفسه & 9 \\
\hline ذاتية & 1,0 & $r, \wedge$ & ضعف إعداد المعلم التزبوي & $1 \cdot$ \\
\hline طلابية & 1,or & $r, \cdot \varepsilon$ & |ضعف شعور الطلبة بالانتماء للمدرسة & 11 \\
\hline
\end{tabular}

\section{ثالثاً : مشكلات المعلمين بحسب الخبرة:}

لمعرفة أهم المشكلات التي تواجه المعلمين والمعلمات بحسب الخبرة قام الباحثون بدايةً

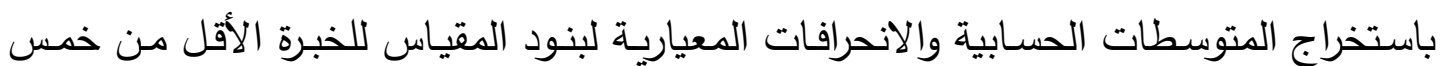
سنوات، والجدول التالي يبين ذلك: جلول رقم (V) المتوسطات الحسابية والانحرافات المميارية لبنود المقياس بالنسبة للخبرة الاققل من خمس سنوات

\begin{tabular}{|c|c|c|c|c|}
\hline نوعالمكلة & $\varepsilon$ & مـ & ـــلات & هـ \\
\hline ذاتية & $1, r$ & $\Gamma, \wedge \wedge$ & ضعف إعداد المعلم التخصصي & 1 \\
\hline طلابية & $1, Y r$ & r,^० & ضعف شعور الطلبة بالانتماء للمدرسة & r \\
\hline ذاتية & $1, r_{0}$ & $r, v \uparrow$ & ضعف إعداد المعلم التربوي & r \\
\hline أولياء الأمور & $1, r 7$ & $r, v \cdot$ & سيطرة الجانب النظري وحشو المعلومات & $\varepsilon$ \\
\hline ذاتية & 1, ro & $r, 0$. & ضعف الوعي باستخدام التقنيات التكنولوجية & 0 \\
\hline ذاتية & $1, \varepsilon$ & $r, r \varepsilon$ & |عدم القدرة على إدارة الصف & 7 \\
\hline أولياء الأمور & $1, \varepsilon r$ & $r, r_{1}$ & تدخل أولياء الأمور في عمل المعلمين & $\mathrm{v}$ \\
\hline
\end{tabular}


ولمعرفة أهم المشكلات التي تواجه المعلمين والمعلمات في الخبرة التدريسية الأكثر من خمس سنوات وأقل من عشر سنوات، قام الباحثون باستخراج المتوسطات الحسابية والانحرافات المعيارية لبنود المقياس، والجدول التالي يبين ذلك:

جلول رقمـ (1) المتوسطات الحسابية والانحرافات المعيارية لبنود المقياس بالنسبة للخبرة الاكثثر من خمس سنوات وأقل من المشر سنوات

\begin{tabular}{|c|c|c|c|c|}
\hline نــــوع المشكلــــة & $\varepsilon$ & هـ & الششك المك & مر \\
\hline 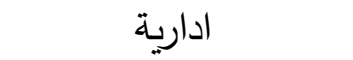 & 1,11 & $r, q$. & إدارة المدرسة لا تعير اهتماما للمشاكل المدرسية & 1 \\
\hline ذاتية & 1,19 & $r, q r$ & ضـف إعداد المعلم التخصصي & r \\
\hline المنهج وطرق التدريس & $1, Y r$ & $r, \wedge V$ & سيطرة الجانب النظري وحشو المعلومات & r \\
\hline 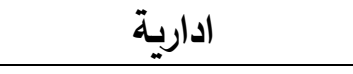 & $1, r_{1}$ & $r, v)$ & |إدارة المدرسة ترهق المعلمين بالاعمال الكتابية & $\varepsilon$ \\
\hline المنهج وطرق التدريس & $1, r v$ & $r, \uparrow$ & |المناهج تركيز على طرق التدريس التقليدية & 0 \\
\hline المنهج وطرق التدريس & $1, \varepsilon r$ & $r, \varepsilon r$ & ضعف ارتباط المنهاج بحاجات الطلبة & 7 \\
\hline ذاتية & $1, \varepsilon$ & $r, r v$ & ضـف دافعية المعلم نحو التدريس & v \\
\hline المنهج وطرق التدريس & $1, \leqslant 0$ & r, To & |التقيد التام بالمنهج التقليدي & $\wedge$ \\
\hline المنهج وطرق التدريس & $1, \leqslant 0$ & $r, 11$ & |عدم توفر وسائل تعليمية كافية & 9 \\
\hline
\end{tabular}

ولمعرفة أهم المشكلات التي تواجه معلمي ومعلمات اللغة العربية في المرحلة المتوسطة الذين خبرتهم أكثر من عشر سنوات، قام الباحث باستخراج المتوسطات الحسابية والانحرافات المعيارية لبنود المقياس، والجدول التالي يبين ذلك: جلول رقم (9) المتوسطات الحسابية والانحر افات المعيارية لبنود المقياس بالنسبة للمعلمين والمعلمات الذين خبرتهم أكثر من عشر سنوات الماتهوات

\begin{tabular}{|c|c|c|c|c|}
\hline نـــــوع الشكلــــة & $\varepsilon$ & هـ & 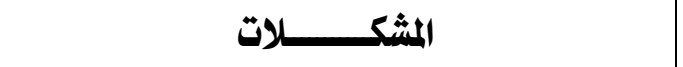 & هـ \\
\hline 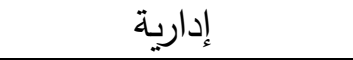 & $1, r$ & $r, \wedge \vee$ & إدارة المدرسة لا تعير اهتماما للمشاكل المدرسية & 1 \\
\hline المنهج وطرق التربس & $1, r_{0}$ & r,^० & |التقيد التام بالمنهج التقليدي & r \\
\hline المنهج وطرق التدريس & $1, Y_{7}$ & r,Ar & سيطرة الجانب النظري وحشو المعلومات & r \\
\hline أولياء الأمور & I, & $r, \vee \cdot$ & ضـفف تفاعل أولياء الأمور في متابعة الابناء & $\varepsilon$ \\
\hline المنهج وطرق التريس & 1, a & r,Tr & |ضعف ارتباط المنهاج بحاجات الطلبة & 0 \\
\hline ذاتية & $1, \mathrm{r} \Lambda$ & r, & ضعف دافعية المعلم نحو التدريس & 7 \\
\hline المنهج وطرق التدريس & $1, \varepsilon r$ & $r, r \leqslant$ & ضعف دور الموجهين نحو المعلمين & $\mathrm{V}$ \\
\hline 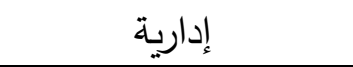 & $1, \leqslant 7$ & $r, \cdot 10$ & التسيب الإدارة المدرسية & $\wedge$ \\
\hline
\end{tabular}




\section{رابعا : مشكلات المعلميز بحسب الجنس :}

لمعرفة أهم المشكلات التي تواجه المعلمين والمعلمات بحسب الجنس قام الباحثون بدايةً باستخراج المتوسطات الحسـابية والانحرافات المعياريـة لبنود المقياس للذكور، والجدول التالي يبين ذلك:

جلول رقم (•1) المتوسطات الحسابية والانحرافات المعيارية لبنود المقياس بالنسبة للنكور

\begin{tabular}{|c|c|c|c|c|}
\hline نـــوعالمشكـــة & $\varepsilon$ & مـ & 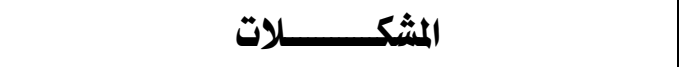 & هـ \\
\hline ذاتية & $1, r_{0}$ & $r, V r$ & ضعف إعداد المعلم التخصصي & 1 \\
\hline 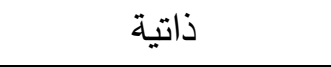 & $1, Y 9$ & $r, 7)$ & ضعف الوعي باستخدام التقنيات التكنولوجية & r \\
\hline المنهج وطرق التدريس & 1,1 & $r, \leqslant q$ & |سيطرة الجانب النظري وحشو المعلومات & $r$ \\
\hline المنهج وطرق التدريس & ( & $r, \varepsilon$. & ضعف ارتباط المنهاج بحاجات الطلبة & $\varepsilon$ \\
\hline طلابية & $1, \mu \wedge$ & $r, r v$ & ضعف شعور الطلبة بالانتماء للمدرسة & 0 \\
\hline 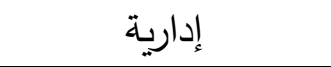 & $1, \varepsilon$ & $r, 1 \wedge$ & |إدارة المدرسة لا تعير اهتماما للمشاكل المدرسية & 7 \\
\hline 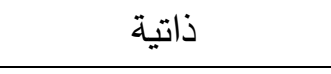 & $1, r q$ & $r, 1 \cdot$ & ضعف دافعية المعلم نحو التدريس & V \\
\hline المنهج وطرق التدريس & $1, \varepsilon 1$ & $r, \cdot q$ & | التقيد التام بالمنهج التقليدي & $\Lambda$ \\
\hline 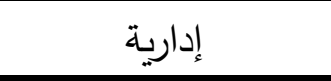 & $1, \varepsilon r$ & $r, \cdot \Lambda$ & مبالغة إدارة المدرسة في التركيز على الانضباط & 9 \\
\hline
\end{tabular}

ثم قام الباحث باستخراج المتوسطات الحسـابية والانحرافات المعياريـة لبنود المقيـاس للإناث، والجدول التالي يبين ذلك:

جلول رقم (11) المتوسطات الحسابية والانحرافات المميارية لبنود المقياس بالنسبة للإناث

\begin{tabular}{|c|c|c|c|c|}
\hline نــــوع الشكلـــة & $\varepsilon$ & مـ & 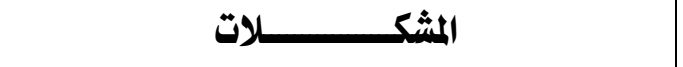 & هـ \\
\hline 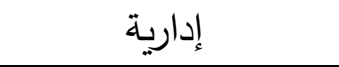 & $1, r$ & $r, v$. & إدارة المدرسة لا تعير اهتماما للمشاكل المدرسية & 1 \\
\hline المنهج وطرق التدريس & $1, Y \wedge$ & $r, 01$ & ضعف ارتباط المنهاج بحاجات الطلبة & r \\
\hline 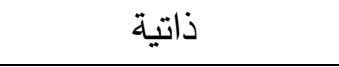 & 1,19 & $r, \varepsilon \vee$ & ضـفف إعداد المعلم التخصصي & r \\
\hline المنهج وطرق التدري & $1, \mu_{1}$ & $r, r q$ & سيطرة الجانب النظري وحشو المعلومات & r \\
\hline المنهج وطرق التدريس & $1, \pi \leqslant$ & 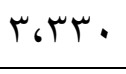 & |التقيد التام بالمنهج التقليدي & $\varepsilon$ \\
\hline المنهج وطرق التدريس & $1, r_{0}$ & $r, r t$ & عدم توفر وسائل تعليمية كافية & 0 \\
\hline 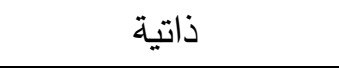 & $1, r$ & 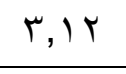 & ضعف دافعية المعلم نحو التدريس & 7 \\
\hline 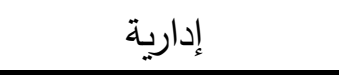 & $1, \leqslant 0$ & $r, \cdot r$ & ضـعف الدعم المالي للأنشطة المدرسية & V \\
\hline
\end{tabular}


هل توجد فروق ذات دلالة إحصائية في المشكلات بين المعلمين حسب نوع الطلبة؟ للتحقق من هذا السؤال قام الباحثون باستخدام اختبار ( ت ) للعينات المستقلة والجدول التالي يبين ذلك.

جلول رقم (r) المتوسطات الحسابية والانحرافات المعيارية لمشكلات المعلمين حسب الجنس

\begin{tabular}{|c|c|c|c|c|c|c|}
\hline \multirow[t]{2}{*}{ اللالة } & \multirow[t]{2}{*}{ قيمة ت } & \multicolumn{2}{|c|}{ معلمي طلبة الاحتياجات } & \multicolumn{2}{|c|}{ معلمي الطلبة العاديسن } & \\
\hline & & $\varepsilon$ & مـ D D & $\varepsilon$ & 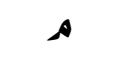 & \\
\hline$\cdot, 0$ & r, ro & $\mid r, \cdot 1$ & $V_{1, Y I}$ & سT, & $\varepsilon r . V \uparrow$ & مشكلات المعلمين \\
\hline
\end{tabular}

بالنظر إلى الجدول السابق يتبين وجود فروق دالة إحصائياً عند مستوى 0 . , • بين كل من معلمي الطلبة العاديين ومعلمي طلبة ذوي الاحتياجات الخاصـة في المشكلات، ومن خلال المتوسطات الحسابية يتبين أن الفروق لصالح معلمي طلبة الاحتياجات الخاصة.

السؤال الثالث للدراسة:

هـل توجـــ فـروق ذات دلالــة إحصــائية فـي المشـكلات بـين المعلمسين الطلبـة

حسب الخبرة التدريسية؟

للتحقق مـن هذا السـؤال قـام البـاحثون باسـتخراج المتوسـات الحسـابية والانحرافـات المعياريـة في مشكلات معلمي ومعلمـات اللغـة العربيـة في المرحلـة المتوسطة حسب الخبرة، والجدول التالي يبين ذلك: جلول رقم (r ا ) المتوسطات الحسابية والانحرافات المعيارية لمشكلات المعلمين بالنسبة للخبرة

\begin{tabular}{|c|c|c|}
\hline$\varepsilon$ & 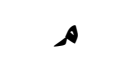 & الخـــــــــــبرة \\
\hline 10,19 & $\vee \wedge, \varepsilon \varepsilon$ & خمس سنوات وأقل \\
\hline$|7, r|$ & $V 7,70$ & أكثر من 0 سنوات و • 1 سنوات \\
\hline $17, \mathrm{rV}$ & $V \varepsilon, 11$ & أكثر من · ا سنوات \\
\hline
\end{tabular}

يتضـح من خـلال الجدول السـابق وجود بعض الاختلافات بين المتوسطات الحسـابية للأبعاد المختلفة مما يوجب إجراء اختبار أنوفا . 
للتحقق من الفروق في المتوسطات الحسابية للمشكلات في المجموعات الثلاث، قام الباحثون بإجراء تحليل التباين الأحادي، والجدول التالي يبين نتائج ذلك التحليل. جدول رقم (\&) اختبار أنوفا للمشكلات بحسب الخبرة

\begin{tabular}{|c|c|c|c|c|c|}
\hline الدلالة & قيمة (ف) & متوسط المربعات & درجات الحرية & مجموع المربعات & الأبعاد \\
\hline \multirow[t]{3}{*}{ • rvo } & $1, \cdot r$ & M, M, & r & Tr, & بين المجموعات \\
\hline & & $r \cdot r$, ror & 0.0 & $1 \leq r \cdot \vee \wedge, \nearrow 7$ & داخل المجموعات \\
\hline & & & $0 . v$ & $1 \leq Y \vee 97, \wedge \leq$ & المجموع \\
\hline
\end{tabular}

يتضـح مـن الجدول السـابق عدم وجـود فروق ذات دلالـة إحصـائية بـين المجموعـات

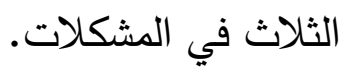

\section{السؤال الرابع للدراستة:}

هل توجد فروق ذات دلالة إحصائية في المشكلات بين المعلمين حسب الجنس؟ للتحقق من هذا السؤال قام الباحثون باستخدام اختبار (ت) للعينات المستقلة والجدول التالي يبين ذلك.

جدول رقم (10) المتوسطات الحسابية والانحر افات المعيارية لمشكلات المعلمين حسب الجنس

\begin{tabular}{|c|c|c|c|c|c|c|}
\hline \multirow{2}{*}{ الللالة } & \multirow{2}{*}{ قيمةت } & \multicolumn{2}{|c|}{ إناث } & \multicolumn{2}{|c|}{ ذكور } & \\
\hline & & $\varepsilon$ & 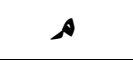 & $\varepsilon$ & 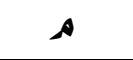 & \\
\hline$\cdot, \cdots 1$ & $r, \wedge)$ & $11,7 \varepsilon$ & $1 ., 07$ & $10, .0$ & $V Y, T V$ & مشكلات المعلمين \\
\hline
\end{tabular}

بالنظر إلى الجدول السابق يتبين وجود فروق دالة إحصائياً بين كل من الذكور والإناث في المشكلات، ومن خلال المتوسطات الحسابية يتبين أن الفروق لصالح الإناث.

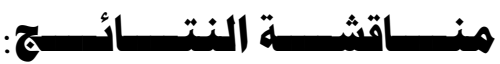

توصـلت الدراسـة إلى عدة نتائج ذات أهميـة حيث هدفت الدراسـة للوقوف على أهـ المشكلات وأكثرها شيوعاً لدى معلمي ومعلمات اللغة العربية من وجهة نظرهم، كما تهدف إلى معرفة أثر متغيرات كل من: (نوع الطلبة، الخبرة، الجنس) على درجة وجود تلك المشكلات التي تضمنتها أداة الدراسة. 
وقد أسفرت الدراسـة أن هناك عدة مشكلات تعاني منها عينـة الدراسـة بشكل عام من أهمها: ضـفف إعداد المعلم التخصصي، سيطرة الجانب النظري وحشو المعلومـات، ضـف ارتباط المنهاج بحاجـات الطلبـة، ضعف دافعيـة المعلم نحو التدريس، إدارة المدرسـة لا تعير اهتماما للمشاكل المدرسية، التقيد التام بالمنهج التقليدي، ضعف تفاعل أولياء الأمور في متابعة الأبناء، ضعف الوعي باستخدام التقنيات التكنولوجية، ضعف شعور الطلبة بالانتماء للمدرسـة، وتتوافق تلك النتائج في جانب أو أخر مـع كثير مـن الدراسـات السـابقة منهـا: دراسـة السبر

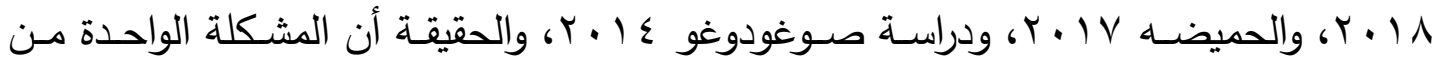
المشكلات التي أظهرتها نتيجة الدراسـة الحالية تعد عقبة كفيلة بضعف الطلبة في مادة اللغـة العربية، بل وفي المواد الأخرى لأن دراسة المواد معتمدة على اللغة العربية، فكيف وقد اجتمعت تلك المشكلات على المعلمين والطلبة، وتكررت أغلب المشكلات عند فئات العينة فضـلاً أنها ظهرت عندهم بشكل عام، والمتأمل في تلك المشكلات يجد أنها شملت كل أبعاد المقياس وخاصة ما يتعلق بذات المعلم من حيث عدم تمكنه في تخصص اللغة العربية والتي بلا شك كانت من أسباب عدم دافعيته نحو التدريس، ومن فقد الدافعية قل عنده الاهتمام نحو تطوير قدراته واسـتخدام التقنيـات التكنولوجيـة، ولعل البعض يرجـع ضـعف المعلم إلى كليـات إعداد المعلمين التي بحاجة إلى مراجعة مدخلاتها ومخرجاتها في تخصص اللغة العربية، ولعل النقاش يسترسل ليصل إلى كيفية اختيار كليات إعداد المعلمين لمعلمي اللغة العربية، حيث أن نسب القبول في تخصص اللغـة العربية عـادة مـا تكون أقل النسب، وبالتالي فإن عدد كبير ممن تخصصوا معلمين للغة العربية لم تكن من ميولهم ولا من رغباتهم الأولى، ولعلها تكون الاختيار الأخير في كلية إعداد المعلمين، وبالتالي فإن كثير مدن تخصص معلماً للغـة العربية كانت نسبهم الدراسية في الثانوية من أقل النسب، وقد يكون ضعيفاً في اللغة العربية، ففاقد الثيئ لا

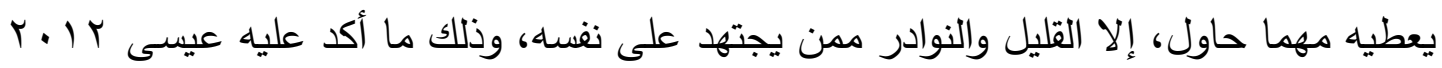
أن هنالك علاقة بين مستوى إعداد المعلمين في المادة الدراسية التي سيقومون بتدريسها وبين أدائهم وتأثيرهم في قاعات التدريس بإضافة مفردات الكفايات التدريسية الخاصة بكل مادة إليها، وكلما زاد كم محتوى المادة الدراسية المقدم لمعلمي الغد كان أفضل ناتجاً وأحسن رئياً. 
ويعد المنهاج ركناً مههاً في العملية التعليمية، وقد أظهرت نتائج الدراسـة أن هناك عدة

مشكلات في المنهاج منها: سيطرة الجانب النظري وحشو المعلومـات، ضـفف ارتباط المنهاج بحاجات الطلبة، وتقييد المعلم تقييداً تاماً بمنهج ثابت لا يستطيع أن يعدل فيه أو يضيف إليه بعض المستجدات، فإن المعلم بهذه الحالة يصبح ملقن ويوجه الطلبه نحو الحفظ فقط، ويجعل المعلم يكثر من وسآئل الضبط وحفظ النظام بعدم الحركة والتزام الهدوء طوال فترة التدريس مما يجعل الحياة المدرسية في أعين الطلبة جافة وجامدة، وبالتالي إذا كانت المناهج جامدة وبعيدة عن حاجات الطلبة وفيها الكثير من حشو المعلومات فماذا نتوقع من الطالب إلا أن يكون ضعيفاً ولا يشعر بالانتماء للمدرسة وخاصـة إذا كان الطلبة من ذوي الاحتياجات الخاصـة، وواكب ذلك ضسعف تفاعل أولياء الأمسور في متابعـة الأبناء، ومـع كثرة تلك المشـاكل وصسوبة معالجتها يترتب على ذلك أن إدارة المدرسة تألف مثل تلك المشكلات فلا تعير لها انتباها، وهكذا تتكرر المشكلات ولا يوجد لها حل ناجع، ولعل السبب الرئيس يرجع لضـف مستوى مدخلات تخصص اللغة العربية في كليات إعداد المعلمين وبالتالي ضعف المخرجات، وتبدأ المشكلات ففاقد الثيئ لا يعطيه. وبالنسبة للمعلمين الذين يدرسون الطلبة العاديين، فلم تختلف المشكلات عندهم عن المشكلات التي ظهرت عند العينـة بشكل عام، وبالنسبة للمعلمين الذين يدرسون في فصول الطلبة ذوي الاحتياجات الخاصة فقد توافقوا في ست مشكلات من المشكلات التي ظهرت عند العينـة بشكل كامل وبرزت عندهم خمس مشكلات تمثلت في: التركيز على طرق التدريس التقليدية، ضعف دور الموجهين نحو المعلمين، قدرات الطلاب أقل من مستوى المواد الدراسية، ضعف اعتماد الطالب على نفسه، ضعف إعداد المعلم التربوي. ويعتبر توافقهم مع المشكلات التي ظهرت عند عينة الدراسة بشكل عام أمر متوقع فهم تخرجوا من نفس كليات إعداد المعلمين ولهم نفس الظروف ولكنهم تفردوا ببعض المشكلات مثل: قدرات الطلاب أقل من مستوى المواد الدراسية، ضعف اعتماد الطالب على نفسه، ولعل السبب أن الطـلاب من ذوي الاحتياجـات الخاصـة وبعضهـم طلبـة بطه تعلم ومستوى ذكائهم منخفض وبالتالي فقدراتهم العقليـة منخفضـه واعتمـادهم على أنفسهم ضـعيف، كمـا بـرزت عدة مشكلات 
أخرى منهـا : ضـف إعداد المعلم التربـوي وذلك بسبب أن المعلم غير مؤهل لتدريس طلبـة الاحتياجات الخاصة، فضلاً عن عدم معرفته لطرق تدريس ذوي الاحتياجات الخاصـة، وتمتد تلك المشكلات لتصل إلى ضعف دور الموجهين نحو المعلمين الذين يتعاملون مع طلبة الاحتياجات الخاصة بسبب عدم تأهيل الموجهين حول التعامل مع تربية ذوي الاحتياجات الخاصة. وبالنسبة للمشكلات التي ظهرت عند المعلمين بحسب الخبرة، فقد توافقت مع المشكلات التي ظهـرت عند العينـة بشكل عـام، ولكن تفرد المعلمين الجـد الأقـل مـن خمس سـنوات بالمشكلات التالية: ضـفف إعداد المعلم التربوي، عدم القدرة على إدارة الصف، تدخل أولياء الأمور في عمل المعلمين، ولعل بروز مثل هذه المشكلات عند المعلمين الجدد نتيجة منطقية حيث يعانون من قلة الخبرة مما يشعرهم بأنهم لم يتأهلوا تربوياً بشكل جيد وخاصـة عندما لا يستطيعون إدارة الصف بشكل جيد، ولا يستطيعون التعامل الجيذ مع أولياء الأمور مما يجعلهم يشعرون أن كثرة أسئلة أولياء الأمور واستفساراتهم هي نوع من التدخل في عملهم، أو فعلاً أن أولياء الأمور عندما شعروا بقلة خبرة المعلمين كانت لهم بعض المقترحات وبعض التدخلات فيما يحمي حقوق أبنائهم، وقد أشار ستكي توماس Stacy Thomas 9 1 ـ ب أن الأهل يسعون إلى التركيز على سلبيات العملية التعليمية وأخطاء المعلم في حال وجودها مـع التغاضسي عن الإيجابيات، ويؤكد ذلك نتائج دراسـة العجمي والعجمي Y I ب أن من أهم مصسادر الضـغوط المهنية لمعلمي التربية الخاصة: عدم وجود مناهج دراسية مناسبة، والتباين بين مستويات الطلبة المعـاقين، وزيـادة عدد الطـلاب في الفصـول، والتوقعات العاليـة مـن ولي الأمـر، وزيـادة عدد حصص المعلمين، وضعف التقدير من قبل المسئولين، وضعف الدافعية عند الطلاب. وبالنسبة للمعلمين الذين خبرتهم أكثر من خمس سنوات وأقل من عشر سنوات فلم يختلفوا كثيراً عن المشكلات التي ظهرت عند عينة الدراسة بشكل عام، ولم تظهر عندهم ما ظهر عند أقرانهم من بعض المشكلات التي تدل على عدم اكتساب الخبرة مثل عدم إدارة الصف وأنهم غير مؤهلين تربوياً، لكن برزت عندهم مشكلات أخرى تتناسب مع خبرتهم مثل المشكلات التالية: أن إدارة المدرسة ترهق المعلمين بالأعمال الكتابية، وأن المناهج تركز على 
طرق التدريس التقليدية، عدم توفر وسـائل تعليمية كافية، ولعل السبب يرجع أن إدارة المدرسـة تعتمد عليهم في إدارة اللجان وتتظيم الكنترول والإشراف الإداري لما لهم من خبرة ودراية بالعمل فضلاً أنهم أصبحوا متمكنين في التدريس ويسعون إلى التجديد في التدريس واستخدام الوسائل التعليمية الجديدة.

وبالنسبة للمعلمين الذين تزيد خبرتهم عن عشر سنوات فلم يختلفوا كثيراً عن المشكلات التي ظهرت عند عينة الدراسة بشكل عام ولكن برزت عندهم مشكلات أخرى تدل على أنهم ينظرون بنظرة الخبير الذي يقيم الأمور من حوله وينتقد الإدارة المدرسية والتوجيه الفني وأولياء الأمور ولذا برزت عندهم المشكلات التالية: ضعف تفاعل أولياء الأمور في متابعة الأبناء، ضعف دور الموجهين نحو المعلمين، تسيب الإدارة المدرسية، وتتوافق النتيجة مع نتائج دراسـة

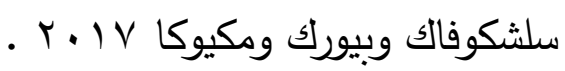
وبالنسـبة للمشـكلات التـي ظهـرت عنـد المعلمـين بحسـب الجـس فلـم تختلـف عـن المشكلات التي ظهرت عند عينة الدراسة بشكل كامل، ولكن برزت عن الذكور المشكلة التالية: مبالغة إدارة المدرسة في التركيز على الانضباط، ولعل ذلك بسبب أن طبيعة الذكور الرجال هم مـن يتحملـون أعبـاء البيــت ويضـطرون للإسـتئذان مـن المدرســة والخـروج لقضـاء مصـالحهم ومصـالح أولادهـم وبيـوتهم ومـن يتولـون مسـؤليته مـن مراجعـات الـوزارات والـدوائر الحكوميـة والمستشفيات وغيرها، وذلك ما يسبب ربكة في جدول المدرسة اليومي، وخاصة إذا ما عرفنا أن معلمي اللغة العربية نصابهم في اليوم لا يقل عن حصتين دراسيتين بسبب كثرة حصص مادة اللغة العربية وقلة أعداد معلي اللغة العربية، وذلك بعكس زملائهح الذين يدرسون مواد دراسية نصيبها في الأسبوع حصة أو حصتين لكل صف دراسي. وبالنسبة للمعلمات فبرزت عندهن المشكلتين التاليتين: عدم توفر وسائل تعليمية كافية، ضـفف الدعم المالي للأنشطة المدرسية، ولعل السبب يرجع إلى ما عرف من شدة العنصر النسـائى في الإدارة والتوجيـه الفني ممـا يجعل المعلمـة تحرص وتجتهد في إحضـار الوسـئل التعليميـة على حسـابها الخـاص، وتتفق جـزء مـن راتبهـا على الوســائل التعليميـة والأنشـة 
المدرسية، وهذا أمر مشاهد ومعروف على مستوى الوزارة، ولذا برزت هذه المشكلتين عند الإناث ولم تظهر عن غيرهن من فئات العينة الأخرى .

وبالنسبة للفروق فقد أوضـحت نتائج الدراسـة وجود فروق دالة إحصـائياً عند مستوى

ه • ، · بـين كـل مسن معلمي الطلبـة العـاديين ومعلمسي طلبـة ذوي الاحتياجـات الخاصــة في المشكلات وهذا مما يدل تعرض معلمي ذوي الاحتياجات الخاصـة لمشكلات أكثر من أقرانهم معلمي الطلبة العاديين بسبب طبيعة عملهم مع الطلبة المعاقين من حيث طرق تدريهم وما يحتاجونـه مـن متابعـة مستمرة للخطـة التربويـة والفرديـة والتـدريس الفردي، وغيرهـا مـن طبيعـة التعامل، وتتوافق هذه النتيجة مع ما توصلت لله دراسة بير r · . ب أن المعلمون العاديون اتجاها ايجابيا نحو الدمج, في حين أظهر معلمو التربية الخاصة اتجاها سلبيا كما أثبت الدراسـة الحالية عدم وجود فروق بين المعلمين تعزى لمتغير الخبرة، وهذه تتوافق مـع مـا توصـلت إليـه دراسـة العجمي والعجمي r ا • ب بعدم وجود فروق في مصـادر الضـوط بين معلمي التربية الخاصـة تعزى لمتغير الخبرة، ولعل السبب يرجع كون المعلمين يشتكون من أغلب المشكلات موضوع الدراسة، فالمتأمل في المشكلات عند الفئات الثلاث: أقل من خمس سنوات، وما بين الخمس والعشر ستوات وأكثر من عشر سنوات يجد تشابهاً بينهم في أغلب المشكلات، وذلك لما يعيشونه من نفس الظروف فكلهم معلمي لمادة اللغة العربية، ولهم نفس المسئولين مثل رؤساء الأقسام والمدراء والموجهين الفنيين. وبالنسبة لمتغير الجنس قد أظهرت نتائج الدراسـة فروق لصـالح الإناث، وتخالف هذه النتيجة مـا توصـلت لـه دراسـة العجمي والعجمي r ا ـ ب بعدم وجود فروق بين الجنسين في مصادر الضغوط المهنية بالنسبة لمعلمي مدارس التربية الخاصـة، ولعل السبب في ذلك يرجع لاختلاف العينة ولطبيعة العينة حيث أن عينة الدراسة الحالية وخاصـة المعلمين من جنسيات عربيـة وكويتيـة وخليجيـة ومصـرية وأردنيـة وتونسية، أمـا المعلمـات فإنـه يغلب عليهن أنهـن كويتيات، فضلاً أن مشكلات المعلمات اختلفت عن مشكلات المعلمين . 
1- رفع نسب القبول في كليات إعداد المعلم وخاصة في تخصص معلم اللغة العربية. r-مراجعة صحائف التخرج الخاصة بإعداد معلمي اللغة العربية، وزيادة المقررات العلمية التخصصية والمتناسبة مع مناهج المرحلة المتوسطة . r- رفع مستوى المعلمين في الجانبين العلمي والفني ببعض البرامج والدورات المتخصصة من قبل التوجيه الفني، والاستعانة بأعضاء هيئة التدريس في الجامعة. ع - مراجعة المنـاهج التعليميـة وربطها بحاجـات الطالب وحذف مـا يمكن أن تحتويـه مـن

$$
\text { معلومات غير ضرورية. }
$$

0- تشجيع المعلمين وزيادة دافعيتهم نحو مهنة التريس بحل مشاكلهم المهنية، والعمل على تسهيل ما يواجههم من عقبات.

1-دراسة أسباب مشاكل المعلمين والعمل على حلها، بما يتواكب مع طبيعة العصر . V- تطـوير أسـاليب التعليم وطـرق التدريس والاستعانة بالتكنولوجيـا الحديثـة والأسـاليب المنظورة في التعليم داخل وخارج الصف الدراسي. ^-ربط المادة الدراسية من خلال الأنشطة والمشاريع بواقع الحياة اليومية للطالب مما يزيد شعور الطلبة بالانتماء للمدرسة. 


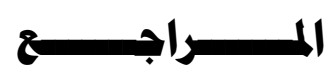

1- إبراهيم، على (9 ( ـ ץ). الصعوبات التدريسية لمادة الأحياء في المرحلة الثانوية من وجهة

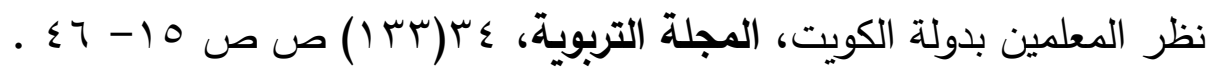

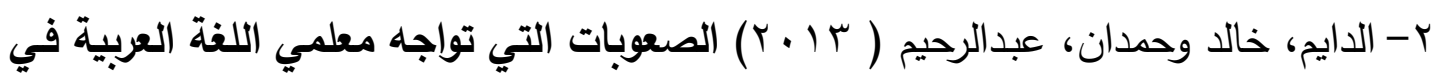

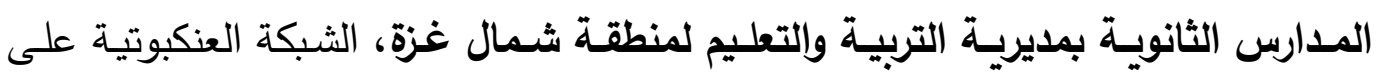
https://platform.almanhal.com/Files/2/72448 الرابط التالي: r- الحميضده، عبدالعزيز عثمان (Y V V V). أبرز المشكلات التدريسية التي تواجه معلمي اللغة العربية في مدارس تعليم الكبار المتوسطة الحكومية بمدينة الرياض، مجلة العلوم التربويـة

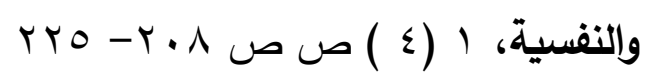

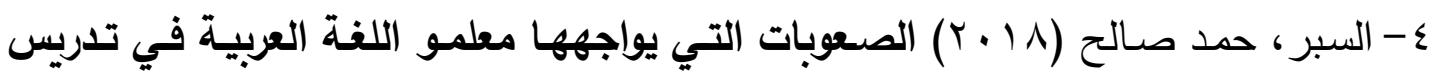
مقرر الكفايات اللغوية في المرحلة الثانوية، رسالة ماجستير غير منشورة مودعة في مكتبة جامعة الملك سعود.

0- السلطان، عبدالمحسن حجي (ع بـ () تقويم أداء معلمي اللغة العربية الجودة الثـاملة، رسالة ماجستير غير منشورة مودعة في مكتبة جامعة الإمام محمد بن سعود الإسلامية .

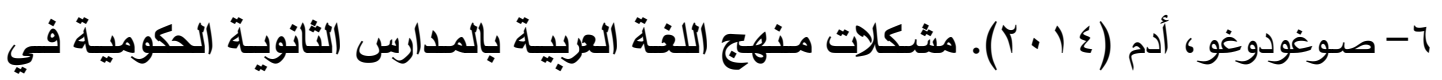
جمهورية مالي من وجهة نظر معلميها، رسالة ماجستير غير منشورة من جامعة الملك سعود.

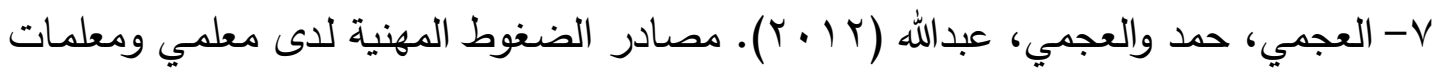
مدارس التربية الخاصة بدولة الكويت، المجلة المصرية للتدراسـات النفسية، r YVV) ص

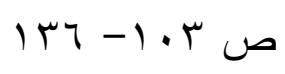

^- عطيف، يحي (Y (Y Y). مشكلات تدريس مقرر "لغتي الخالدة" للصف الأول المتوسط وفق تصورات مشرفي اللغة العربية ومعلميها، رسالة ماجستير غير منشورة مودعة في مكتبة جامعة الملك سعود

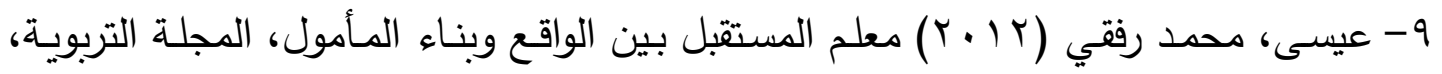
إصدار خاص (V) • (V) 
• 1- عبدالجواد، إياد (9 1 • ( ). الأناشيد المتضمنه في كتب (لغتنا الجميلة) الجديدة للصفوف من

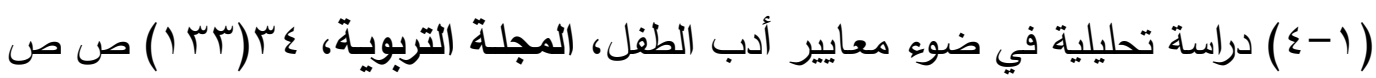

$$
\text { rr. }-19 V
$$

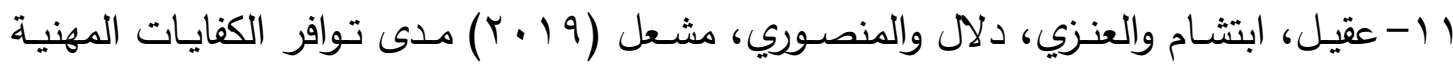
لمعلمي الرياضيات في المرحلة الابتدائية في ضوء المعايير العالمية ( NCTM) مجلـة

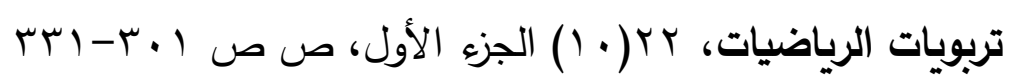

r ا - الفيفي، يحي حسن (V V . . r). واقع توظيف التقنيات التربوية في تدريس اللغة العربية من وجهة نظر مديري المدارس ومعلمي اللفة العربية، رسالة دكتوراه غير منشورة مودعة في مكتبة جامعة السودان للعلوم والتكنولوجيا.

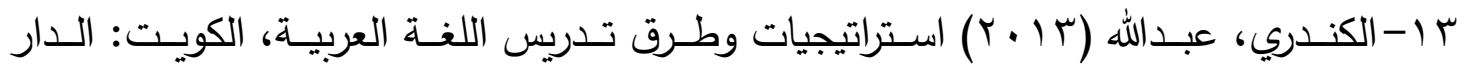
الأكاديمية .

ع ا- المشعان، عويد ( . . . ץ). مصادر الضغوط المهنية لدى المدرسين في المرحلة المتوسطة بدولة الكويت وعلاقتها بالإضطرابات النفسية الجسمية. مجلة العلوم الاجتماعية، ( (Y)، $.97-77$

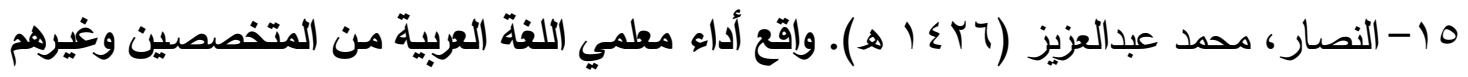
في الصفوف الأولية، رسالة ماجستير غير منشورة مودعة في مكتبة جامعة الملك سعود . 16- AL-Yaseen, W.( 2018). Motivations of Choose Teaching as a Career: A Perspective of English Language Student-Teachers at Kuwait University. The Educational. Journal,32(127) p p 11-35

17- Beyer, J.R. (2002). A study of attitudes toward inclusion of learning handicapped secondary students at Silver Valley High School (doctoral desertation, Pepperdine University) DAI-A 62/10, P.33-43.

18- Bozdogab, A. E. \& Uzoglu, M. (2015). Science and Technology Teachers' Opinions about problems Faced While Teaching Eighth "'grade Science Unit "Force and Motion" and Suggestions for Solutions. Journal of Turkish Seience Education, 12(1), 57-70. 
19- Cross, T. \&Coleman, J. (2003) · phenomenology and its implications for gifted studies research. Investigation the lebensuelt of academically gifted students attending elementary magnet scool. Journal of the education of gifted, V $26 \mathrm{~N} 3$ - spr.

20- Derrick Meador (2019), "7 Factors that Make Teaching So Challenging" ،thoughtco, Retrieved 13-12-2019. Edited.

21- Lal,R.\& Shergill, S. S. (2012). A Comparative Study of Jop Satisfaction and Attitude Towards Education Among Male And Female Teachers Of Degree Colleges, International Journal of Marketing, 1(1), 57-65

22- Stacy Thomas (2019). "What are the Challenges in Teaching Profession?" ،elephantjournal, Retrieved 13-12-2019. Edited.

23- Sliskovic, A., Buric, I,. Macuka, I. (2017). The Voice of Croatian Elementary School Teachers: Qualitati Analysis of the Teachers' perspective on Their Profession. Teachers and Teaching: Theory and Practice, 23(5), 518-531. 


\begin{tabular}{|c|c|c|c|c|c|c|c|}
\hline 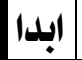 & نادرا & احيانا & غالبا & دائما & العبــــ & & هـ \\
\hline \multicolumn{8}{|c|}{ المشكلات الادارية } \\
\hline & & & & & | تسيب الإدارة المدرسية & 1 & 1 \\
\hline & & & & & إدارة المدرسة لا تعير اهتماما للمشاكل المدرسية & r & r \\
\hline & & & & & |إدارة المدرسة ترهق المعلمين بالاعمال الكتابية & r & r \\
\hline & & & & & |ضعف الدعم المالي للأنشطة المدرسية & $\varepsilon$ & $\varepsilon$ \\
\hline & & & & & |مبالغة إدارة المدرسة في التركيز على الانضباط & 0 & 0 \\
\hline \multicolumn{8}{|c|}{ مشكلات المنهج وطرق التدريس } \\
\hline & & & & & |عدم توفر وسائل تعليمية كافية & 1 & 7 \\
\hline & & & & & |التقيد التام بالمنهج التقليدي & r & V \\
\hline & & & & & ضعف أساليب التقويم المتبعة في تقويم الطلبة & r & $\Lambda$ \\
\hline & & & & & |سيطرة الجانب النظري وحشو المعلومات & $\varepsilon$ & 9 \\
\hline & & & & & |المناهج تركيز على طرق التدريس التقليدية & 0 & 1. \\
\hline & & & & & ضعف دور الموجهين نحو المعلمين & 7 & 11 \\
\hline & & & & & ضعف ارتباط المنهاج بحاجات الطلبة & V & ir \\
\hline \multicolumn{8}{|c|}{ المشكلات الطلابية } \\
\hline & & & & & |قدرات الطلاب أقل من مستوى المواد الدراسية & 1 & 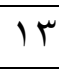 \\
\hline & & & & & ضعف اعتماد الطالب على نفسه & r & $1 \varepsilon$ \\
\hline & & & & & |ضعف استجابة الطلبة لتعليمات المعلم & r & 10 \\
\hline & & & & & ضعف رغبة الطلبة في الدراسة & $\varepsilon$ & 17 \\
\hline & & & & & تعدد الطلبة إيذاء المعلم (تثويش، إساءة، عدم الاحترام) & 0 & IV \\
\hline & & & & & |ضعف شعور الطلبة بالانتماء للمدرسة & 7 & 11 \\
\hline \multicolumn{8}{|c|}{ المشكلات الذاتية } \\
\hline & & & & & ضـفف دافعية المعلم نحو التدريس & 1 & 19 \\
\hline & & & & & ضعف أعداد المعلم التخصصي & r & $r \cdot$ \\
\hline & & & & & ضـف إعداد المعلم التربوي & r & Y \\
\hline & & & & & |عدم القدرة على إدارة الصف & $\varepsilon$ & Yr \\
\hline & & & & & | ضعف الوعي باستخدام التقنيات التكنولوجية & 0 & rr \\
\hline \multicolumn{8}{|c|}{ مشكلات أولياء الأمور } \\
\hline & & & & & |النظرة الدونية من أولياء الأمور & 1 & rs \\
\hline & & & & & |ضعف تفاعل أولياء الأمور في متابعة الابناء & r & ro \\
\hline & & & & & |تدخل أولياء الأمور في عمل المعلمين & r & ry \\
\hline & & & & & تدخل أولياء الأمور في حل الواجبات والأنشطة المدرسية. & $\varepsilon$ & TV \\
\hline
\end{tabular}

